$\left.\right|^{\prime A-6730-M S}$

Informal Report i J $B X-31$

Special Distribution Issued: Morch 1977

\title{
MASTER
}

\section{Uranium Concentrations in Lake and Stream Waters and Sediments from Selected Sites in the Susitna River Basin, Alaska}

\author{
by
}

Dwight E. Hill

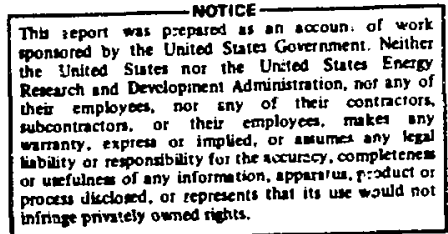

Gernment. Neither the Inited Sut nor the Unted Sutes Energy ar their ofloyces makes iny

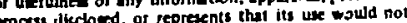
thinast privitely ommod rights.

\section{NOTICE}

PORTIONS OF THIS REPORT ARE ILIEGTPIT. It has been reproduced from the best avaliable copy to permit the broadest possible availab1lity. ...

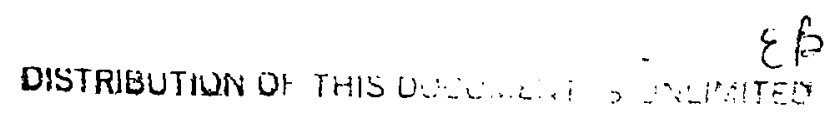


This work was oupported by the US Energs Research and Developsent Adratalstration,

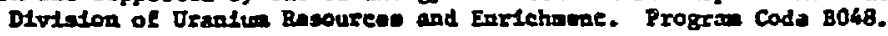

Th1s report wal propared as an account of work spongored by the Dalted States Governeat, Nelther tho Ualted Stutes nor the Tntted States Energy Research and Development Aintalstracton, nor any of thels employeas, nor any of their contractors, subcontractars, or thels employeas, nakes ang warkanty, express 0. longlied, or assumes any legal liability or responsibility for the accuracy, completeness, or usefulaess of agy taformation, upparatus, product, of process disclowed, or represents that its use would nut infrige privately ouned rights. 


\section{CONTENTS}

LIST OF ILLUSTRATIONS IV

LIST OF TABLES iv

$\begin{array}{ll}\text { ABSTRACT } & 1\end{array}$

I. INTRODUCTION 1

II. LOCATION 2

III. FIELD TREATMENT AND ANALYTICAL METHODS 2

Water Samples $\quad 2$

Sediment Samples 4

Fluorometric Method 4

Delayed-Neutron Counting Method 5

IV. RESULTS

ACKNOWLEDGMENTS

REFERENCES CITED $\quad 6$

APPENDIX A Listings of Field Data and Uranium Concentrations (ppb) for Acidified Water Samples from the Susitna River Basin, Alaska A-1

APPENDIX B Listings of Field Data and Uranium Concentrations (ppm) for Sieved Sediment Samples from the Susitna River Basin, Alaska

APPENDIX C Code to Data Listings and Sample Types Used by the Los Alamos Scientific Laboratory in the NURE iydrogeochemical and Stream Sediment Reconnaissance

APPENDIX D Summary of Standard Field and Analytical Procedures Used by the Los Alamos Scientific Laboratory in the NURE Hydrogeochemical and Stream Sediment Reconnatssance 
Fig. No.

1. Location inap for Susitna River basin survey.

Plate No.

I. Sample location overlay for the Susitna River basin, Alaska.

in pocket

II. Uranium concentration ( $\mathrm{ppb}$ ) overlay for water samples from the Susiuna River basin, Alaska.

In pocket

III. Uranium concentration (ppm) overlay for sediment samples from the Susitna River basin, Alaska.

in pocket

\section{LIST OF TABLFS}

Table No.

I. Summary of Water Sample sources and Treatments for the Susitna River basin, Alaska

II. Summary of Sediment Sample Sources and Treatments for the Susitna River basin, Mlaska 
URANIUM CONCENTRATIONS IN LAKE AND STREAM WATERS

AND SEDIMENTS FROM SELECTED SITES

IN THE SUSITNA RIVER BASIN, AIASKA

by

Dwight E. Hill

\begin{abstract}
During the summer of 1976, 141 water and 211 sediment samples were taken from 147 locations in the Susitna River basin in Alaska by the Geophysical Institute of the University of Alaska for the LASL. These samples were taken to provide preliminary information on the uranium ccicentrations in waters and sediments from the Susitna River basir: and to test the analytical methods proposed for the NURE Hydrogeochemical and Stream Sediment Reconnaissance for ur nium in Alaska. The uranium determinations resulting from the fluorometric analysis of the water samples and the delayed-neutron counting of the sediment samples are contained in the Appendixes of this report. The low levels of uranium in the water samples, many of which were below the detectable limit of the LASI fiuorometric technique, indicate that a more sensitive analytical method is needed for the analysis of Alaskan water samples from this area. An overlay showing numbered sample locations and overlays graphically portraying the concentrations of uranium in the water and sediment samples, all at 1:250 000 scale for use with existing USGS ropographic sheets, are also provided as plates.
\end{abstract}

\title{
I. INTRODUCTION
}

The purpose of this report is to make available to the public the resulis of a hydrogeochemical survey for uranium in the stream and lake waters and sediments of the Susitna River basin, Alaska. This work was done by the Los Alamos Sclentific Laboratory (LASL) for the US Energy Research and Development Administration (ERDA) as part of the National Uranium Resource Evaluation (NURE) program. The ERDA Grand Junction Office (GJO), in Grand Junction, Colorado, is responsible for completing the Hydrogeochemical and Stream Sediment Reconnaissance (HSSR) project in the states of New Mexico, Colorado, Wyoming, Montana, and 
Alaska. 1-7 The applicability of hydrogeochemical and stream sediment survey techniques so uranium exploration throughout the world is the subject of an annotated bibliography by $\mathrm{R}$. R. Sharp, Jr. ${ }^{8}$

Between July 10 and July 26, 1976, a total of 141. water and 211 sediment samples were takeil from 147 locations in the Susitna River basin and vicinity, Alaska. These samples were taken by personnel of the Geophysical Institute of the University of Alaska (GIUA) under the direction of Dr. Robert B. Forbes. They were taken at the request of the LASL to obtain information on uranium concentrations in waters and sediments for use in planning future HS:jR work in adjacent parts of Alaska. The sample locations were chosen by GIUA personnel as part of a larger sampling program they were carrying out in the Susitna and Copper River basins. The field data and uranium concentrations for each of the water and sediment samples collected are listed in Appendixes $A$ and $B$, and the parameters included in these listings are defined in Appendix $C$. Methods used in taking and analyzing the samples are set forth in Appendix $D$.

\section{LOCATION}

The location of the area covered by this survey is approximately $280 \mathrm{~km}$ northeast of Anchorage and is shown in Fig. 1. It is surrounded on the west by the Talkeetna Nountains, on the east by the Wrangell Mountains, on the south by the Chugach Kountains, and on the north by the Alaska Range. The study area is drained by both the Susitna and Copper River systems, with the largest number of sample 1ocatious (122, or $83 \%$ of the total) being in the Susitna River basin near the conflwence of the Susitna and Maclaren Rivers. The remaining 19 sample locations are mear Paxson Lake in the Gulkana River drainage of the Copper River basin. These sample locations are shown on Plate $I$, which iss designed to overlay the US Geological Survey (USGS) $3^{\circ}$ topographic map sheet's entitled "Talkeetna Mountains" and "Gulkana" as shown in Fig. 1. Detalled information on the geology, mineral occurrences, and radiometric investigations has been published by severa? investigators. $9-17$

\section{FIELD TREATRENT AND ANALYTICAL METHODS}

A summary of the standard field procedures as well as the analytical methods is contained in Appendix D. Several of the parameters listed under Field Measure ents in Appendixes A and B (air temperature, water temperature, $\mathrm{pH}$, speciffic conductance, and scintillometer reading) were not taken at the time of sampling because of a lack of equipment.

\section{Water Samples:}

All water samples were taken in $25-\mathrm{ml}$ polyethylene containers which were pre-washed in ritric acid, rinsed with distilled water, and capped before shipment to the field. Each water sample was acidified to a pH of approximately 1 by the addition of $8 \mathrm{M}$ reagent grade nitric acid. This was done to inhibit the growth of biolegical matter, which can concentrate uranium, as well as to prevent adsorption of uranium on the walls of the polyethylene containers. Such acidification was the only treatment given the vater samples taken in this study. The uranium concentrations in tie water samples are graphically shown on Plate II. A summary of the water sample sources and treatments is given in Table I. 

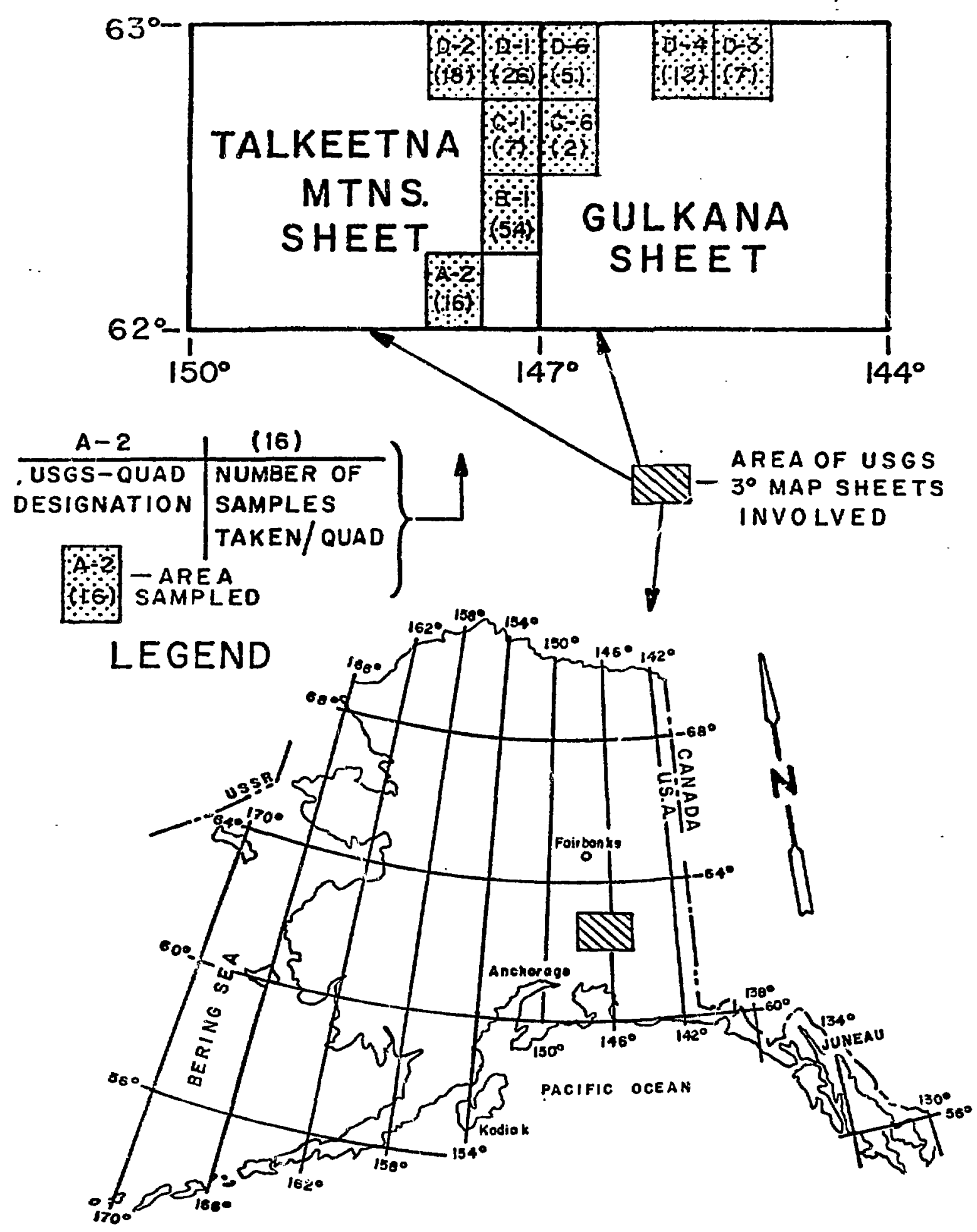

Fig. 1

Location map for Susitna River basin survey. 
TABLE I

\section{SUMMARY OF WATER SAMPLE SOURCES AND TREATMENTS \\ THE SUSITNA RIVER BASIN, ALASKA}

\begin{tabular}{lcc}
$\begin{array}{l}\text { Sample } \\
\text { Source }\end{array}$ & $\begin{array}{c}\text { Sample } \\
\text { Treatment }\end{array}$ & $\begin{array}{c}\text { Number of } \\
\text { Samfles }\end{array}$ \\
\cline { 2 - 3 } $\begin{array}{l}\text { Stream } \\
\text { Natural pond }\end{array}$ & $\begin{array}{c}\text { Acidified only } \\
\text { Acidified only }\end{array}$ & 95 \\
& Total number of water samples & 141
\end{tabular}

Sedinent Samples

The sediment samples taken in the study were placed in polyethylene bags at the time of sampling and sent directly to the LASL. Upon receipt at the LASL, the sediments were dried in an oven at a temperature of $\leq 100^{\circ} \mathrm{C}$ and sieved to obtain the -100 mesh fraction. Replicate sediment samples taken at several locations are indicated by a digit other than zero in the replicate colunns of the data listings in Appendix B. On the uranium concentration overlay for sediment (Plate III), the sing?e uranium value shown for locations from which replicate samples were taken is the average concentration for all samples taken at that location. A summary of the sediment sample sources and treatments is given in Table II.

TABLE II

SUMMARY OF SEDIMENT SAMPLE SOURCES AND TREATMENTS

THE SUSITNA RIVER BASIN, ALASKA

\begin{tabular}{llr}
$\begin{array}{llr}\text { Siample } \\
\text { Source }\end{array}$ & $\begin{array}{c}\text { Sample } \\
\text { Treatment }\end{array}$ & $\begin{array}{r}\text { Number of } \\
\text { Samples }\end{array}$ \\
\cline { 2 - 3 } Wet stream & Dried, sieved -100 mesh & 151 \\
Wet natural pond & Dried, sieved -100 mesh & 57 \\
Dry' stream & Dried, sieved -100 mesh & 3
\end{tabular}

Total number of sediment samples 211

ancludes replicates.

Fluorometric Method

A11 water samples were analyzed for uranium by fluorometry. The fluoro.. metric technique used at the LASL is presently the most economic one available and was developed for maximum sensitivity. The lower detection limit for this method is about. 0.2 parts per billion ( $\mathrm{ppb}$ ) of uranium. Duplicate measurements are made on eacl sample and then averaged to give the uranium value in the listing. Any sample with a uranium level below the detectable limit of $0.2 \mathrm{ppb}$ 
is reported as $0.1 \mathrm{ppb}$. A detailed description of the fluorometric method used by the LASL is contained in a report by Hises, et al.18

Delayed-Neutron Counting Method

All sediment samples were analyzed by delayed-neutron counting (DNC) for total uranium content in an 8-MW light-water research reactor at the LASL. Each dried and sieved sedimeri sample was loaded into a 4-ml polyethylene rabbit, inserted into the reactor for irradiation, and removed from the reactor and counted with specially designed neutron counters. The minimum sensitivity of the technique used is 0.01 parts per million (ppm) of uranium.

IV.

\section{RESULTS}

The results of the uranium analyses of the 141 water and 211 sediment samples taken in this study are given in Appendixes A and B, and the sample locations and uraniua concentrations are shown on Plates $I$, II, and III. Plate $I$ is the sample location overlay for the study. The sample numbers shown on Plate I are the last four digits of the six-digit LASL sample number given in the listings in Appendixes $A$ and $B$.

Plate II is the uranium concentration overlay for all water samples taken, with the uranium concentrations shown in ppl. The uranium concentrations in the water samples are low (that for all but one sample falls below $1.0 \mathrm{ppb}$ ), ranging between $0.1 \mathrm{ppb}$ (below the limit of detection) and $6.31 \mathrm{ppb}$, with the mean being $0.21 \mathrm{ppb}$. The los levels of uranium in the water samples, many of which were below the detectable limit of the LASL fluororatric technique, indicate that a more sensitive analytical method is needed for the analysis of Alaskan water samples from this area.

Plate III is a uraniun concentration overlay for all sediment samples taken, with the uraniun concentrations shown in ppm. The uranium concentrations in the sediments range between $0.3 \mathrm{ppm}$ and $4.6 \mathrm{ppm}$, with a mean of $1.75 \mathrm{ppm}$. Whenever replicate sediment samples were taken, the uranium value shown on the conceritation overlay is an average of all samples taken at that location.

\section{ACKNOWLEDGMENTS}

Acknowledgrent is due the Geophysical Institute of the University of Alaska, whose fersonnel, under the direction of Dr. Robert B. Forbes, collected the samples reported upon herein. The fluorometric analyses of uranium in the water samples were done by the LASL Analytical Chemistry Group, CMB-1, of the Chemistry and Materials-Science Division, under the supervision of Glenn R. Waterbury and William H. Ashley. The determinations of uranium in sediments by delayedneutron counting were done by the Research Reactor Group, P-2, of the Physics Division, under the supervision of Merle E. Bunker and Michael M. Minor. The effort of Jesse Cheadle III and Richard J. Beckman, of the Energy Systems and Statistics Group, Q-12, of the Energy Division, in management of the data and production of sample location and concentration overlay maps is also greatly appreciated. Acknowledgment is likewise made of Alcarto R. Marquez and Patricia 0 'Rourke, both of the Geochemical Applications Group, G-5, in the illustrating and typing of this report. Lastly, the collective efforts of the LASL Group G-5 in designing the sample collection and treatment procedures, the data collecion, handling, and output formats, and the standardized methods making the timeiy reporting of this data possible are gratefully acknowledged. 


\section{REFERENCES CITED}

1. Sharp, R. R., Jr., 1976, Hydrogeochemical and stream sediment survey of the National Uranium Resource Evaluation program, the Rocky Mountain states of New Mexico, Colorado, Wyoming, and Montana, and the state of Alaska, AprilJune 1975, GJBX-19(76), US ERDA, Grand Junction, 48 p.

2. Sharp, R. R., Jr. and Morris, W. A., 1976, Hydrogeochemtcal and stream sediment survey of the National Uranium Resource Evaluation program, the Rocky Mountain states of New Mexico, Colorado, Wyoming, and Montana, and the state of Alaska, July-September 1975, GJBX-25(76), US ERDA, Grand Junction, 47 p.

3. Sharp, R. R., Jr. and Aamodt, P. L., 1976, Hydrogeochemical and stream sedimert survey of the National Uranium Resource Evaluation program, the Rocky Mountain states of New Mexico, Colorado, Wyoming, and Montana, and the state of Alaska, October-December 1975, GJBX-38(76), US ERDA, Grand Junction, 86 p.

4. Sharp, R. R., Jr., Morris, W. A., and Aamodt, P. L., 1976, Hydrogeochemical and strean sediment survey of the National Uranium Resource Evaluation program, the Rocky Mountain states of Ner Mexico, Colorado, Wyoming, and Montana, and the state of Alaska, January-March 1976, GJBX-39(76), US ERDA, Grand Junct:on, $56 \mathrm{p}$.

5. Morris, H. A. and Aamodt, P. L., 1976, Hydrogeochemical and stream sediment reconnaissance of the National Uranium Resolirce Evaluation program, the Rocky Mountain states of New Mexico, Colorado, Wyoming, and Montana, and the state of Alaska, April-June 1976, GJBX-65(76), US ERDA, Grand Junction, $25 \mathrm{p}$.

6. Morris, W. A., 1976, Hydrogeochemical and stream sedinent reconnaissance of the National iranium Resource Evaluation progiam, the Rocky Mountain states of New Mexico, Colorado, Wyoming, and Montana, and the state of Alaska, July-September 1976, GJBX-12(77), US ERDA, Grand Junction, 22 p.

7. Aamodt, P. L., Hanse1, J. M., Jr., Minor, M. M., and Beckman, R. J., 1976, Hydrogeochemical and stream sediment reconnaissance of the National Uranium Resource Evaluation program, the Rocky Mountain states of New Mexico, Colorado, Hyoming, and Montana, and the state of Alaska, October-December 1976, GJBX-20(77), US ERDA, Grand Junction, 27 p.

8. Sharp, R. R., Jr., 1.976, one hundred select, annotated references on uranium hydrogeochemical and stream sediment surveying as internationally practiced, Ios Alamos Scientific Laboratory Report LA-6647-MS, Los Alamos, MI.

9. Grantz, A., 1960a, Geologic map of the Talkeetna. Mountains (A-2) quadrangle, Alaska, and the contiguous area to the north and northwest, USGS Misc. Geologic Map I-313 (1:48 000 scale), Wash., DC.

10. Grantz, A., 1960b, Geologic map of Talkeetna Mountains (A-1) quadrangle and the south third of Talkeetna Mountains (B-1) quadrangle, Alaska, USGS Misc. Geologic Map I-314 (1:48 000 scale), Wash., DC. 
11. Beikman, H. M., 1974, Preliminary geologic map of the southeast quarirant of Alaska, USGS Hisc. Field Studies Map, MF 612 ( $1: 1$ 000000 scale), Wash., DC.

12. Cobb, E. H., 1970, Uranium, thoxium, and rare-earth elements in Alaska, issGs Mineral Irvestigations Resources Map. MR-56 (1:2 500000 scale), Wash., DC.

13. Cobb, E. H., 1972a, Metallic mineral resources map of the Talkeetna Mountains quadrangle, Alaska, USGS Misc. Field Studies Map, MF-370 (1:250 000 scale), Wash., DC.

14. Cobb, E. H., 1972b, Metallic mineral resources map of the Gulkana quadrangle, Alaska, USGS Misc. Field stucies Map, MF-419 (1:250 000 scale), Wash., DC.

15. State of Alaska, 1973, Dept. of Natural Resources, Div. of Geological and Geophysical Surveys, Alaska Open File Report 20, Fairbanks, AK, 3 p.

16. Eakins, G. R., 1975, Investigation of Alaska's uranium potential, US ERDA Report GJO-1627, Pt. I, Grand Junction, 437 p.

17. Forbes, R. B., 1975, Investigation of Alaska's uranium potential, US ERDA Report GJO-1627, Pt. II, Grand Junction, 44 p.

18. Hues, A. D., Henicksman, A. L., Ashley, W. H., and Romero, D., I977, The fluorometric determination of uranium in natural waters, Los Alamos Scientific Laboratory Report LA-6683-MS, Los Alamos, NM, Il F. 


\author{
APPENDIX A \\ LISTINGS OF FIELD DATA AND URANIUM CONCENTRATIONS \\ FOR \\ ACIDIFIED WATER SAMPLES \\ FROM THE \\ SUSITNA RIVER BASIN, ALASKA \\ SAMPLES ANALYZED BY FLUOROMETRY
}

(See Appendix C for Codes to Listings) 


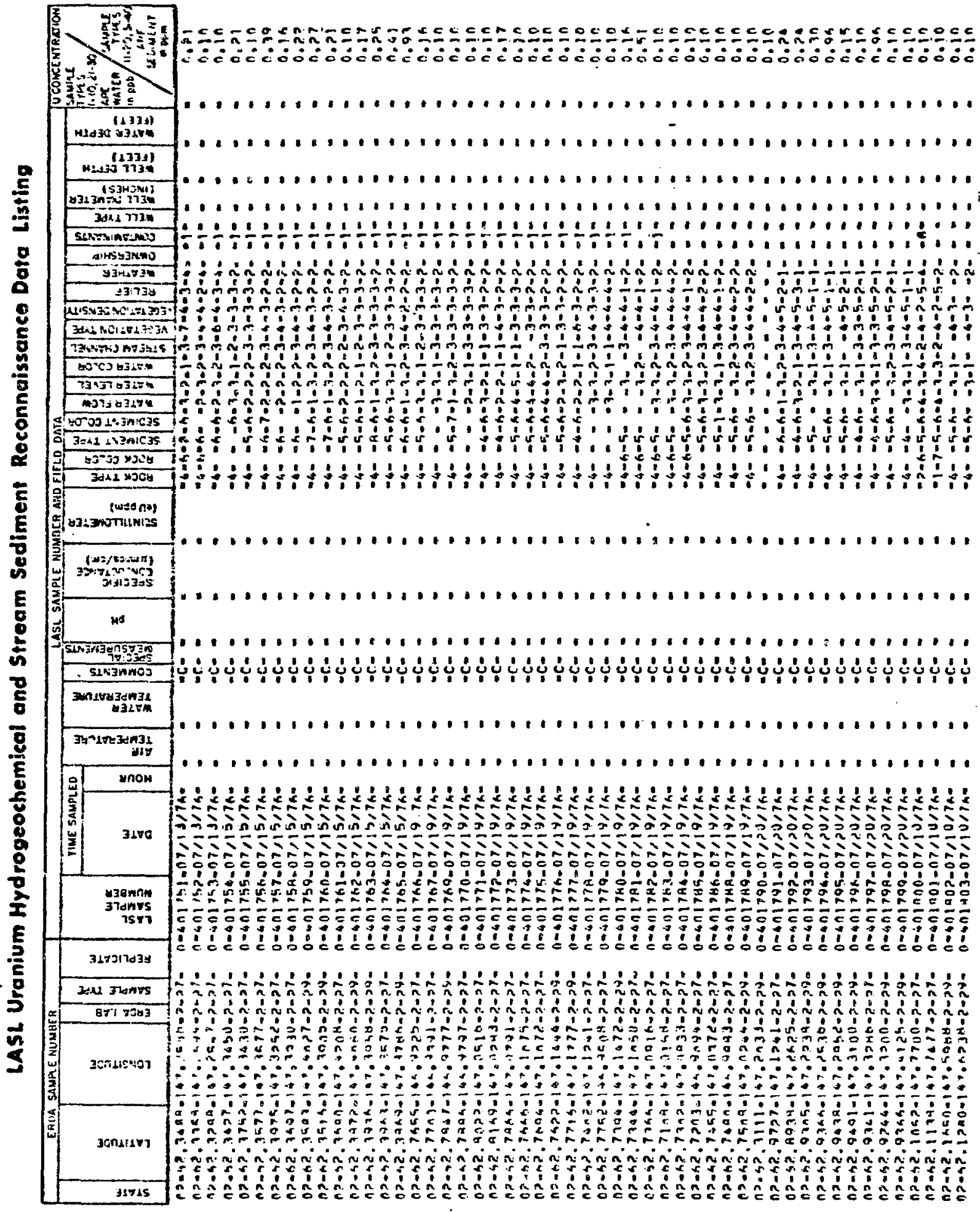




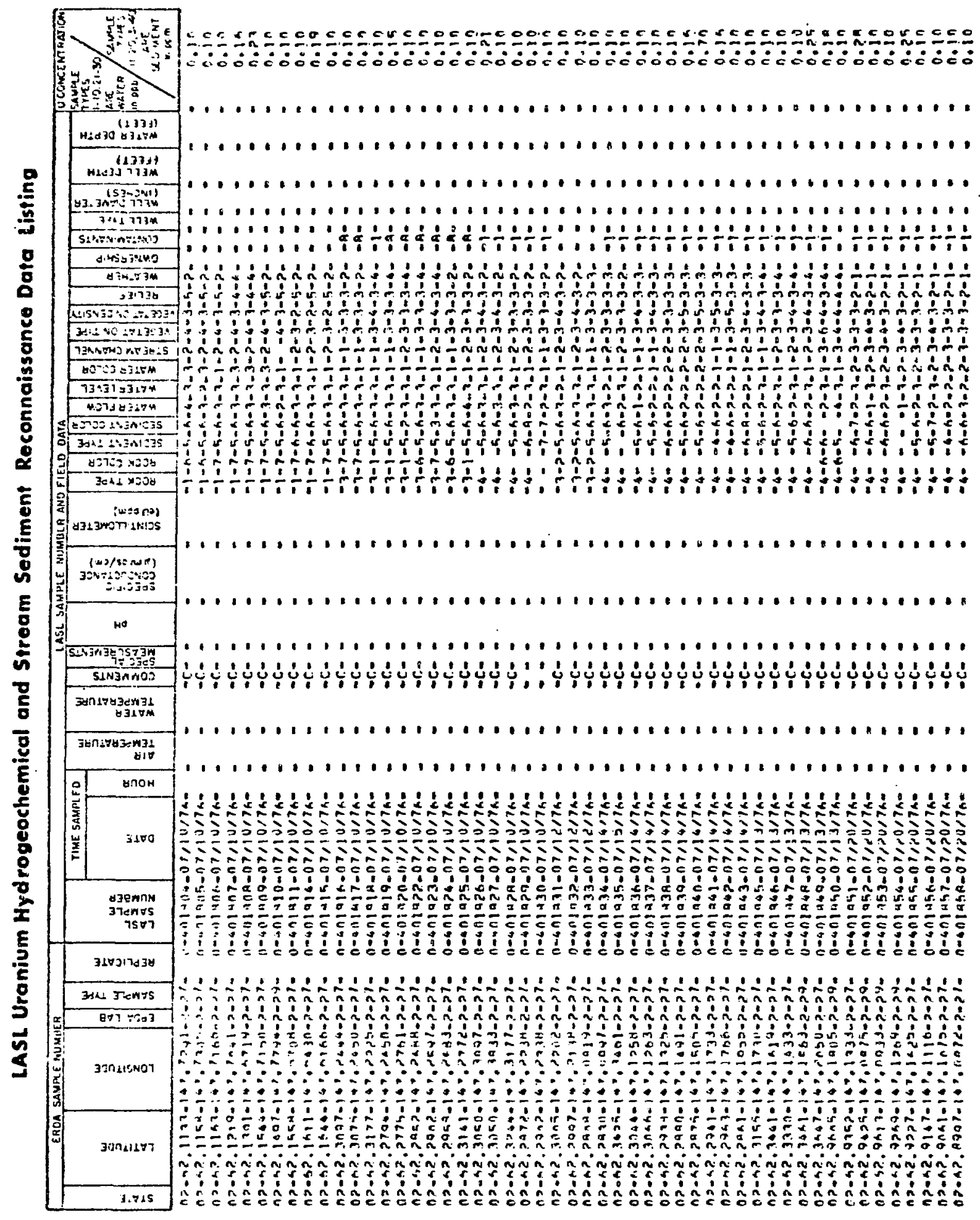


LASL Uranium Hydrogeochemical and Siroam Sediment Reconnaissance Data Listing

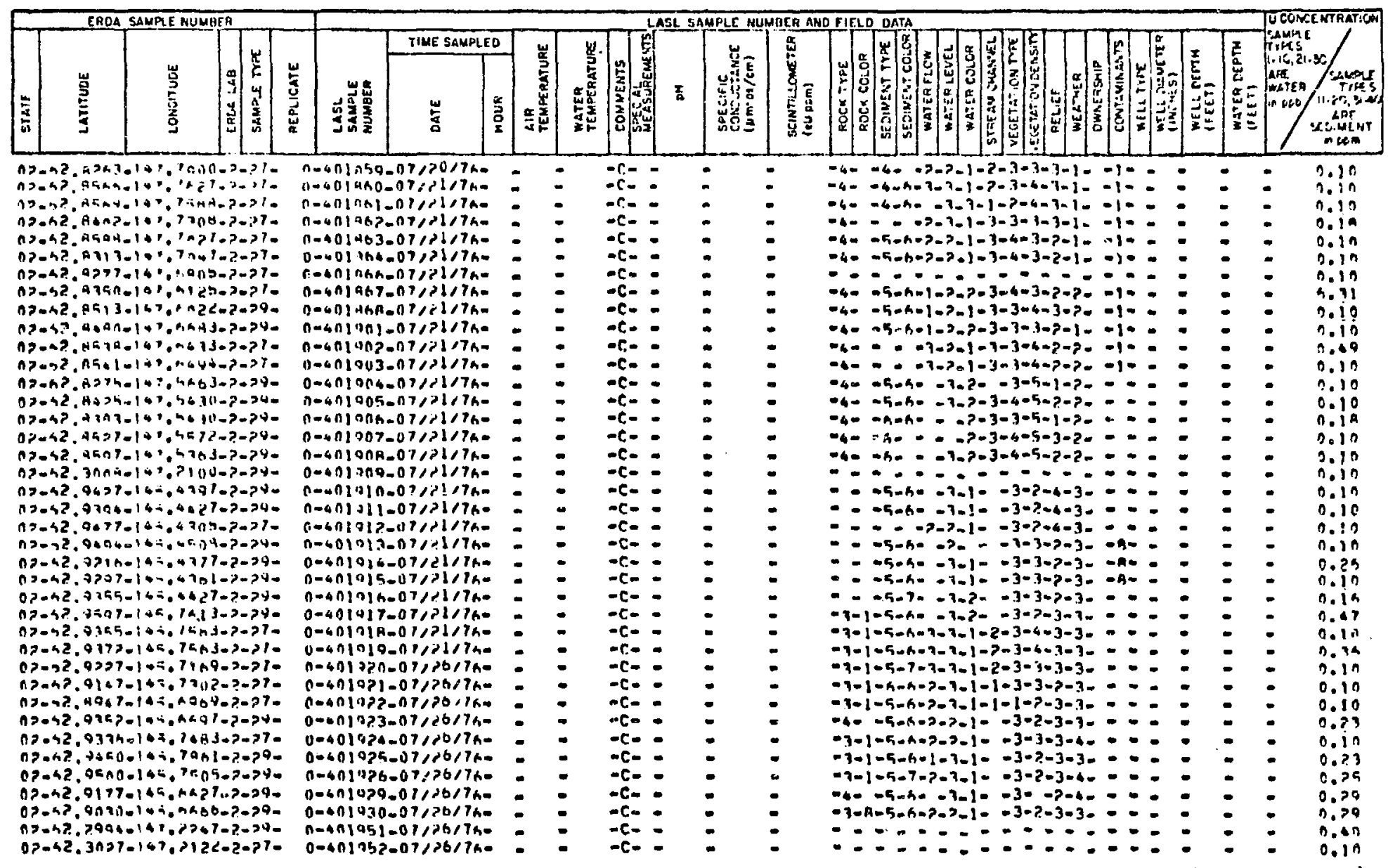




\section{APPENDIX B}

LISTINGS OF FIELD DATA AND URANIUM CONCENTRATIONS

FOR

DRIED AND SIEVED SEDIMENT SAMPLES

FROM THE

SUSITNA RIVER BASIN, ALASKA

SAM?LES ANALYZED BY DELAYED-NEUTRON COUNTING 


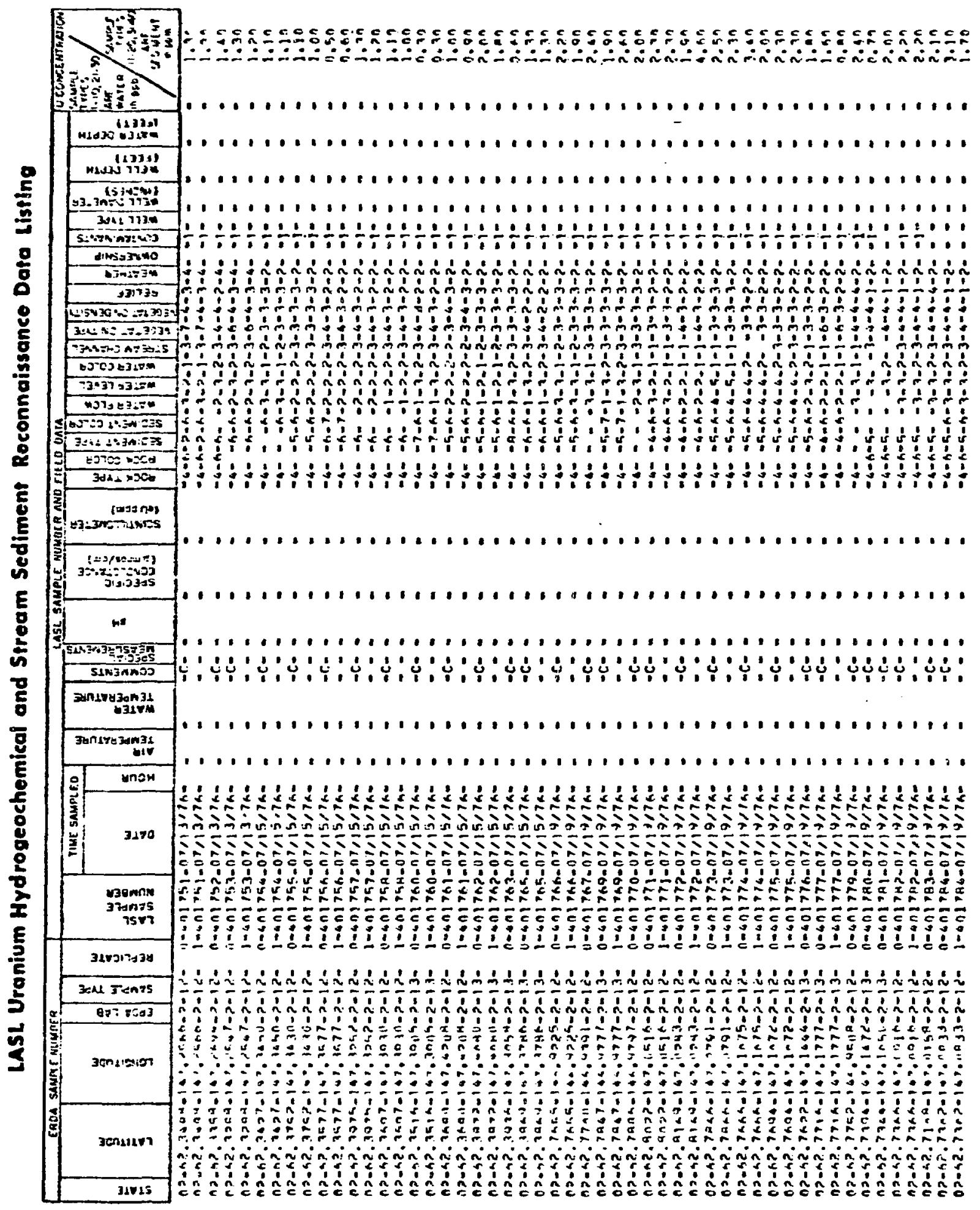




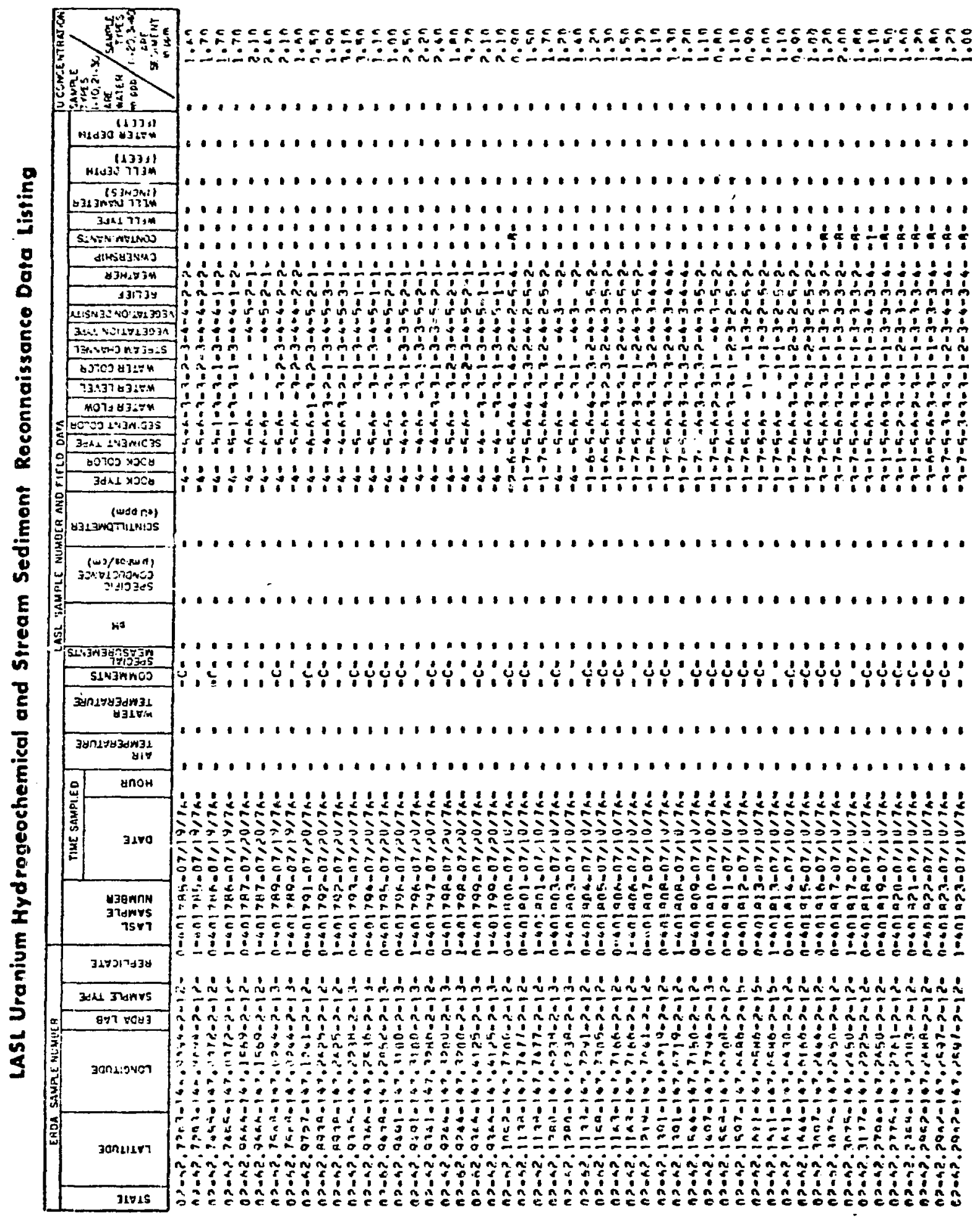




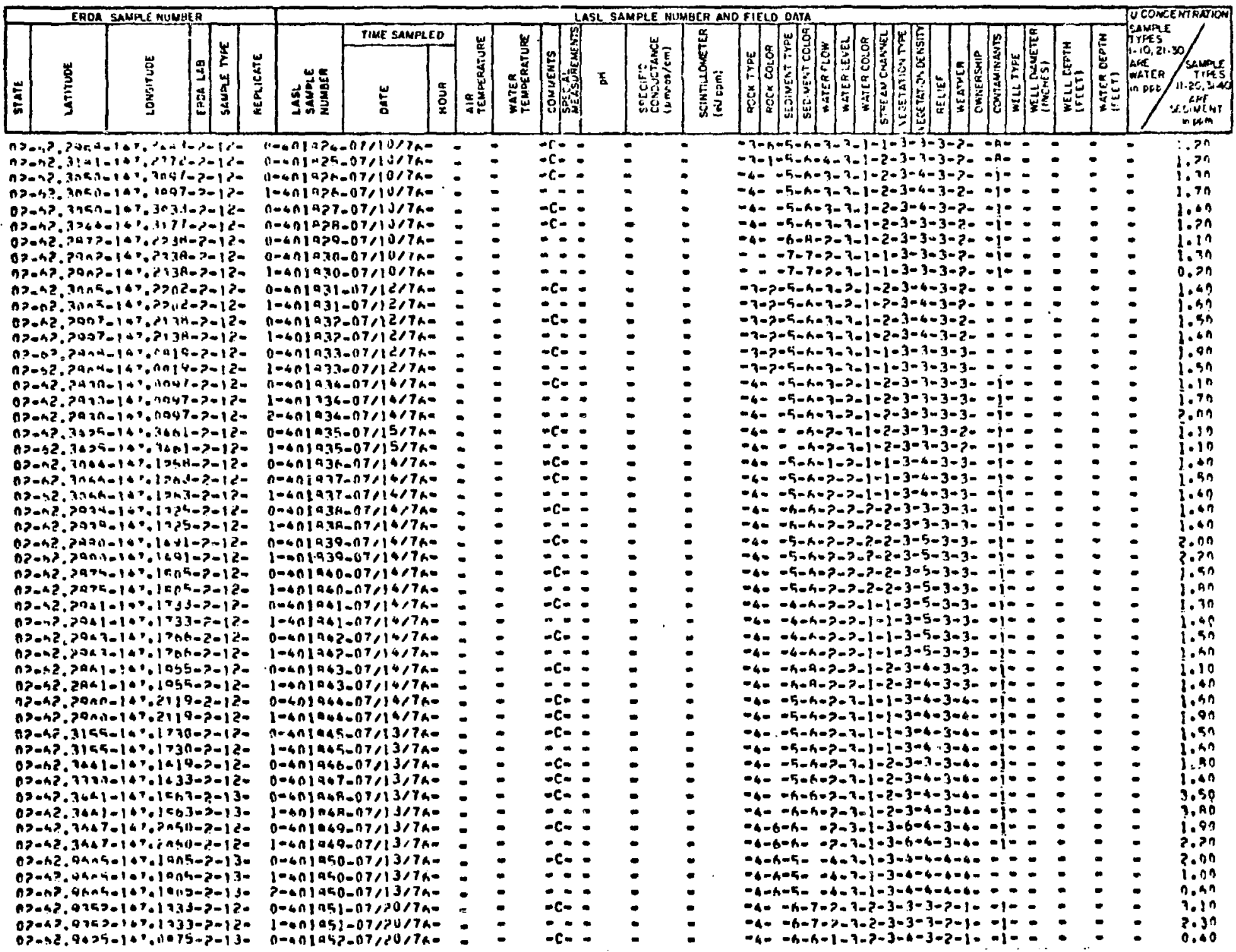


LASL Uranium Hydrogeochemical and Stream Sediment Reconnaissance Dafa Listing

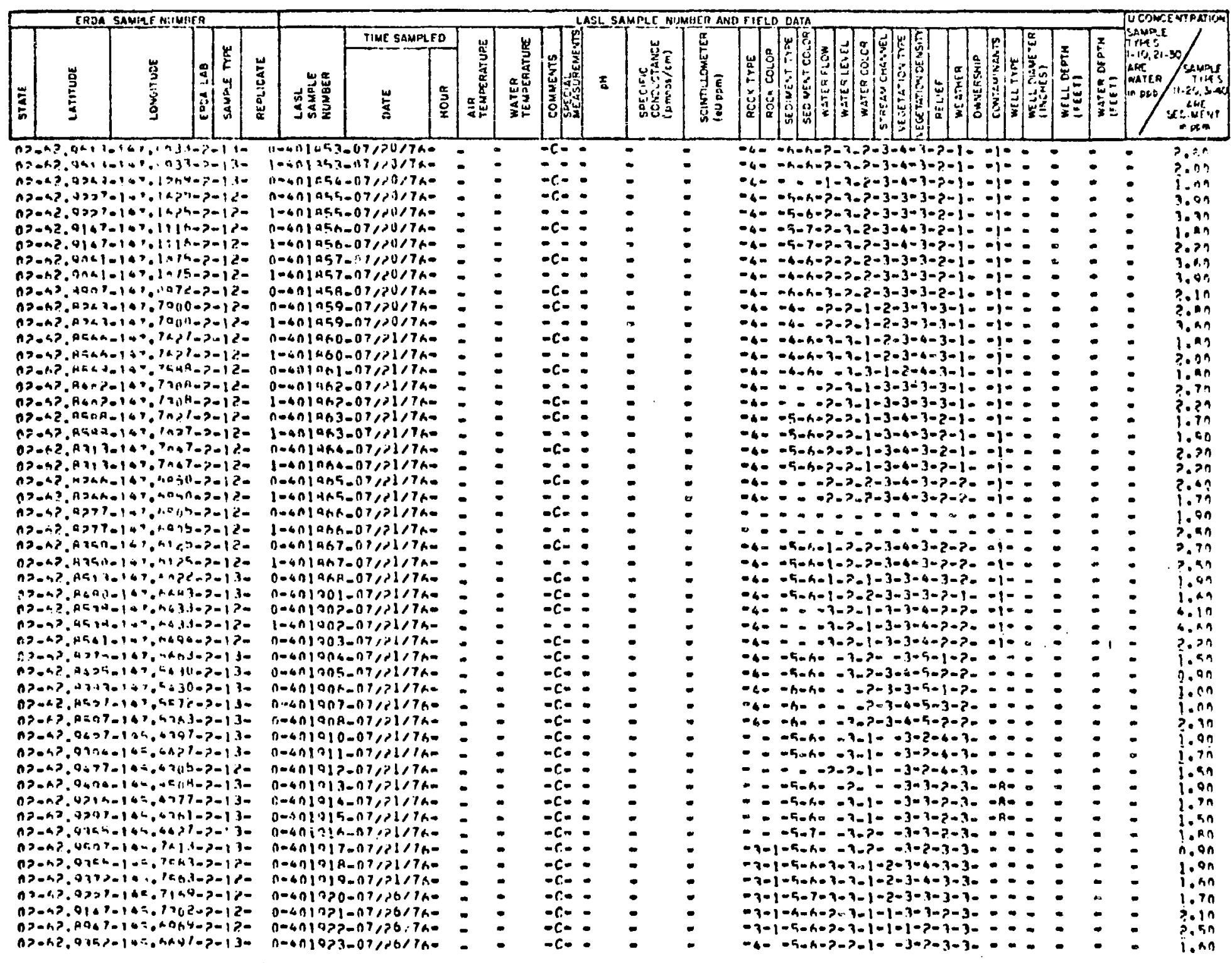


LASL Uranium Hydrogeochemical and Stream Sediment Reconnaissance Dota Listing

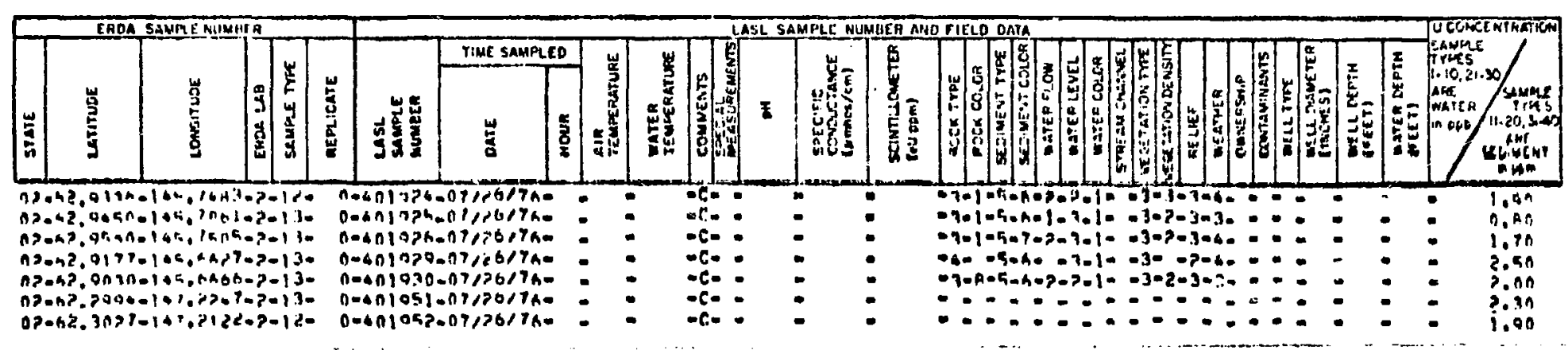


APPENDIX C

CODE TO DATA LISTINGS AND SAMPLE TYPES USED

BY

THE LOS ALAMOS SCIENTIFIC LABORATORY

IN THE'

NURE HYDROGEOCHEMICAL AND STREAM SEDIMENT RECONNAISSANCE

ITEM C-I

EXPLANATION OF CODE USED IN THE LASL HSSR DATA LISTINGS

AND

ITEM C-II

NUMERICAI KEY TO SAMPLE TYPES TAKEN IN THE LASL HSSR 


\author{
APPENDIX ITEM $\mathrm{C}-\mathrm{I}$ \\ EXPLANATION OF CODE USED \\ IN \\ OPEN-FILE LISTINGS OF HSSR DATA \\ PROVIDED BY
}

THE LOS ALAMOS SCIENTIFIC LABORATORY

ERDA SAMPLE NOMBER

STATE: A two-digit Federal Information Processing Standards (FIPS) code, designating the state from which each sample came. For the states being covered by the LASL, the code numbers are:
Alaska $=02$
New Mexico $=35$
Colorado $=08$
Wyoming $=56$

Montana $=30$

LATITUDE AND LONGITUDE: Sample location, in degrees and decimal degrees to four places. However, though generally much better, locational accuracy cannot be guaranteed closer than about 300 meters (1000 feet).

ERDA LAB: An Energy Research and Development Administration (ERDA) one-digit identifier designating the national laboratory responsible for taking the sample and the data shown In the listing, as well as providing the analysis giving the uranium and other elemental concentrations, if any. The LASL is designated by the Number 2.

SAMPLE TYPE: A two-digit identifier which specifically designates the pertinent properties defining the sample type to which the listed data relate. For explanation of the code used, refer to the attached "Numerical Key and Specifications for Sample Types Taken by the LASL" (Appendix Item C-II).

REPLICATE: A three-digit sequential number assigned to indicate a multiple sample of a single sample type from a single location. The largest number in use indicates the most recent sample taken, and there will always be smaller sequential numbers representing earlier samples back to 000 , which is the initial sample from any given location. Except in the case of special studies, there will be no replicate samples and this entry will therefore be 000 .

LASL SAMPLE NUMBER AND FIELD DATA

LASL SAMPLE NUMBER: A unique six-digit number permanently assigned by the LASL to every location sampled in each state. For internal use, these numbers are assigned in blocks to the various areas individually treated and reported upon and therefore serve to generally locate the samples within the various states as follows.

Location Numbers

from

from

from

from

from
000001 through 099999

100001 through 199999

200001 through 299999

300001 through 399999

400001 through and above =

\section{State}

$=$ New Mexico

$=$ Colorado

$=$ Wyoming

= Montana

Alaska 
TIME SAIPLED: The DATE that the sample was taken, in terms of the number of the MONTH, followed by the DAY, and Finally the YEAR, separated by slashes, and ti:en the TIME it was taken on that date to the nearest whole HOUR on a military (24hour) clock.

AIR TEMPERATURE: The temperature that was measured in the shade at the time of sampling, to the nearest whole degree Celsius $\left({ }^{\circ} \mathrm{C}\right)$.

WATER TEMPERATURE: The temperature that was measured in the sample water (in situ whenever possible) at the time of sampling, to the nearest one-tenth of a degree Celsius $\left(0.1^{\circ} \mathrm{C}\right)$.

COMMENS: A " $\mathrm{C}$ " in this column indicates that some secondary comment not included in the listing was recorded at the sample location. This information will be used by the LASL in evaluating the data and, if appropriate, it will be mentioned in the final report.

SPECIAL MEASUREMENTS: A "S" in this column indicates that one or more field measurements in addition to those listed were made at the sample location. A description of any special parameters measured, and the measured value at each sample location, will be included in the final HSSR report on the area by the LASL.

$\mathrm{pH}$ : The $\mathrm{pH}$, to the nearest one-tenth (0.1) of a pH unit, that was measured in the water at the sample location at the time of sampling.

SPECIFIC CONDUCTANCE: The conductivity, in $\mu$ thhos $/ \mathrm{cm}$, that was measured in the water at the sample location at the time of sampling.

SCINTILLOMETER: The equivalent uranium (eU), in parts per million (ppm), as measured on a flat ground surface within ten meters of the sample location using a scintillometer fitted with a differential gamma sampler (DGS). The effect of the DGS is to introduce a fixed geometry into the measurement and remove the background.

ROCK TYPE: The single digit in this column provides a general description of the dominant lithologic regime at or near the sample location as given below.

$$
\begin{array}{ll}
1=\text { Sedimentary } & 3=\text { Igneous } \\
2=\text { Metamorphic } & 4=\text { Unknown }
\end{array}
$$

ROCK COLOR: The single digit in this column provides an indication of the observed dominant color of local bedrock exposures at or near the sample location as given below.

$$
\begin{array}{lll}
1=\text { White } / \text { Buff } & 4=\text { Pink } / \text { Red } & 7=\text { Gray } \\
2=\text { Yellow } & 5=\text { Green } & 8=\text { Black } \\
3=\text { Orange } & 6=\text { Brown } & 9=\text { Other }
\end{array}
$$

SEDIMENT TYPE: The single digit in this column provides a subjective evaluation of the dominant sediment type at the sample location as given below.

$$
\begin{aligned}
& 1=\text { Boulders } \\
& 2=\text { Cobbles } \\
& 3=\text { Gravel }
\end{aligned}
$$

$$
\begin{aligned}
4 & =\text { Sand } & 6 & =\text { Muck } \\
5 & =\text { Mud } & 7 & =\text { Other }
\end{aligned}
$$


SEDIMENT COLOR: The single digit in this column indicates the observed dominant color of the bottom sediment (stream channel, lake bed, etc.) at the sample location at the time of sampling as given below.

$$
\begin{array}{lll}
1=\text { White } / \text { Buff } & 4=\text { Pink } / \text { Red } & 7=\text { Gray } \\
2=\text { Yellow } & 5=\text { Green } & 8=\text { Black } \\
3=\text { Orange } & 6=\text { Brown } & 9=\text { Other }
\end{array}
$$

WATER FLOW: The single digit in this column provides a subjective evaluation of the water movement at the sample location at the time of sampling as given below.

$$
\begin{aligned}
& 1=\text { Stagnant } \quad 3 \text { = Moderate } \quad 5=\text { Torrent } \\
& 2=\text { Slow } \quad 4 \text { = Fast }
\end{aligned}
$$

WATER LEVEL: The single digit in this column provides a subjective estimate of water quantity at the time of sampling relative to its usual condition at the sample location as given below.

$$
\begin{aligned}
& 1=\operatorname{Dry} \\
& 2=\text { Low } \\
& 3=\text { Normal } \\
& 5=\text { Flood } \\
& 4 \text { = High }
\end{aligned}
$$

WATER COLOR: The single digit in this column provides a subjective evaluation of suspended load in the sample water as given below.

$$
\begin{array}{lll}
1=\text { Clear } & 3=\text { Cloudy } & 5=\text { Algal } \\
2=\text { Murky } & 4=\text { Muddy } & 6=\text { Other }
\end{array}
$$

STREAM CHANNEL: The single digit here gives a subjective evaluation of stream channel character at the sample location at the time of sampling as given below.

$$
1=\text { Depositing } \quad 2 \text { = Eroding } \quad 3 \text { = Unknown }
$$

VEGETATION TYPE: The single digit in this column provides a subjective evaluation of the dominant plant type in the vicinity of the sample location according to the key below.
$1=$ Conifers
$4=$ Grass
6 = Marsh
$2=$ Deciduous
$5=$ Moss
7 = other
$3=$ Brush $_{1}$

VEGETATION DENSITY: The single digit in this column provides a subjective estimate of the amount of plant cover in the vicinity of the sample location according to the key below.

$$
\begin{aligned}
& 1=\text { Barren } \quad 3=\text { Moderate } \quad 5=\text { Very Dense } \\
& 2 \text { = Sparse } \quad 4=\text { Dense }
\end{aligned}
$$

RELIEF: The single digit in this column provides a subjective evaluation of the topography within a few hundred meters of the sample location according to the key below.

$$
\begin{array}{ll}
1=\text { Flat } & 3=\text { Gentle }(15-60 \mathrm{~m}) \quad 5=\text { High }(>300 \mathrm{~m}) \\
2=\operatorname{Low}(<15 \mathrm{~m}) & 4=\text { Moderate }(60-300 \mathrm{~m})
\end{array}
$$


WEATHER: The single digit in this column gives the observed climatic condition at the sample location at the time of sampling as given by the key belno.

$$
\begin{array}{lll}
1=\text { Clear } & 3=\text { Overcast } & 5=\text { Snowy } \\
2=\text { Partly cloudy } & 4=\text { Rainy } & 6=\text { Other }
\end{array}
$$

OWNERSHIP: The single digit here gives a broad classification of administrative responsibility or general ownership of the land at the sample location according to the key below.

$$
\begin{array}{ll}
1=\text { Federal } & 3=\text { Private } \quad 5=\text { other } \\
2=\text { State } & 4=\text { Indian }
\end{array}
$$

CONTAMINANTS: The single digit here indicates known or suspected local factors likely to influence analytical results according to the key below.

$$
\begin{aligned}
& 1=\text { None } \\
& 2=\text { Mining } \\
& 3=\text { Agriculture }
\end{aligned}
$$

$$
\begin{array}{ll}
4=\text { Industry } & 7=\text { Urban } \\
5=\text { Sewage } & 8=\text { Recrea } \\
6=\text { Power generation } & 9=\text { Other }
\end{array}
$$$$
7=\text { Urban }
$$$$
8 \text { = Recreation }
$$

WELL TYPE: The single digit in this column provices a general description of the type of water well from which the sample was taken (if, in fact, it was a well sample) according to the key below.

$$
\begin{array}{lll}
1=\text { Windmil1- stock } & 4=\text { Suction pump } & 7=\text { Hand bail } \\
2=\text { Windmill-domestic } & 5=\text { Jet pump } & 8=\text { H Hnknown } \\
3=\text { Submersible pump } & 6=\text { Large turbine } & 9=\text { Other }
\end{array}
$$

WELL DIAMETER: The one or two digits (if any) in this column give the measured or estimated inside diameter, in inches, of the casing of the well from which the sample (if taken from a well) came.

WELI DEPTH: The one, two, or three digits (if any) in this column give the total drilled depth from the surface, in feet, of the well from which the sample (if taken from a well) came.

WATER DEPTH: The one, two, or three digits in this colurn give the depth, in feet, from the surface to the standing water in the well, if known (if the sample was taken from a well).

URANIUM CONCENTRATION: The value given in this column is the analytically-derived value of the uranium concentration found in the water sample in parts per billion $(\mathrm{ppb})$, or in the sediment sample in parts per million (ppm). Sample Type Nos.'1 through 10 and 21 through 30 are water samples, with their uranium concentrations given in $\mathrm{ppb}$, while Sample Type Nos. 11 through 20 and 31 through 40 are sediment samples, with their uranium concentration given in ppm. 


\author{
APPENDIX ITEM C-II \\ NUMERICAL KEY AND SPECIFICATIONS \\ FOR SAMPLE TYPES TO BE TAKEN BY \\ THE LOS ALAMOS SCIENTIFIC LABORATORY (LASL) \\ IN \\ THE NATIONAL URANIUM RESOURCE EVALUATION (NURE) \\ HYDROGEOCHEMICAL AND STREAM SEDIMENT RECONNAISSANCE (HSSR)
}

The two-digit number assigned each sample type in these spacifications designates three distinct properties of all sampies taken by the LASL in the NURE HSSR project. These properties are:

(A) The general sample source (i.e., spring or stream or dry stream, etc.);

(B) The sample medium (i.e., water or sediment, etc.); and

(C) The treatment given the sample in the field or laboratory prior to its analysis by the LASL.

The express purpose of this numerical key and the accompanying specifications is to provise the user with the necessary tie between each individual suite of field and laboratory data and the specific type, or form of sample, to which they relate. This key and these specifications therefore define the various sample types to be collected by the IASL in the Energy Research and Development (ERDA) HSSR for araniun. The key numbers are inserted in the appropriate columns of the specially formatted ERDA sample numbering system to positively identify the sample type for all LASL sample data submitted to the Grand Junction office.

\title{
SAMPLE
}

KEV NO.

SOURCE / MEDIUM / TREATMENT

01 - Spring pater sample untreated

02 - Stream vater sample untreated

03 - Well warer sample untreated

04 - Natural pond water sample untreated

05 - Artificial pond water sample untreated

06 - Spring water sample filtered through a 0.45-micron membrane filter and acidified to a $\mathrm{pH}$ of $\leq 1$ with reagent-grade nitric acid (iNO ${ }_{3}$ )

07 - Stream water sample filtered through a 0.45 -micron membrane filter and acidified to a $\mathrm{pH}$ of $\leq 1$ with reagent-grade nitric acid ( $\left.\mathrm{HNO}_{3}\right)$

08 - Well water sample filtered through a 0.45 -micron membrane filter and acidified to a $\mathrm{pH}$ of $\leq 1$ with reagent-grade nitric acid $\left(\mathrm{HNO}_{3}\right)$

09 - Natural pond water sample filtered through a 0.45 -micron membrane filter and acidified to $a \mathrm{pH}$ of $\leq 1$ with reagent-grade nitric acid $\left(\mathrm{HNO}_{3}\right)$

10 - Artificial pond water sample filtered through 20.45 -micron membrane fiicer and acidified to a $\mathrm{pH}$ of $\leq 1$ with reagent-grade nitric acid $\left(\mathrm{HNO}_{3}\right)$ 


\section{SAMFLE}

KEY NO.

SOURCE / MEDIUM / TREATMENT

11 - Wet spring sediment sample drted at $\leq 100^{\circ} \mathrm{C}$ and sieved to -100 mesh through stainless steel sieves

12 - Wet stream sediment sample dried at $\leq 100^{\circ} \mathrm{C}$ and sieved to -100 mesh through stainless steel sieves

13 - Wet natural pond sediment sample dried at $\leq 100^{\circ} \mathrm{C}$ and sieved to -100 mesh through stainless steel sieves

14 - Wet artificial pond sediment sample dried at $\leq 100^{\circ} \mathrm{C}$ and sieved to -100 mesh through stainless steel sieves

15 - Dry stream sediment sample dried at $\leq 100^{\circ} \mathrm{C}$ (if necessary) and sieved to -100 mesh through stainless steel sieves

16 - Wet spring sediment sample dried at $\leq 100^{\circ} \mathrm{C}$ and sieved to -230 mesh through stainless steel sieves

17 - Wet stream sediment sampie dried at $\leq 100^{\circ} \mathrm{C}$ and sieved to -230 mesh through stainless steel sieves

18 - Wet natural pond sediment sample dried at $\leq 100^{\circ} \mathrm{C}$ and sieved to $=230$ mesh through stainless steel sieves

19 - Wet artificial pond sediment sample dried at $\leq 100^{\circ} \mathrm{C}$ and sieved to -230 mesh through stainless steel sieves

20 - Dry stream sediment sample dried at $\leq 100^{\circ} \mathrm{C}$ (if necessary) and sleved to -230 mesh through stainless steel sieves

21 - Spring water sample filtered through a 0.45-micron membrane filter

22 - Stream water sample filtered through a 0.45-micron membrane filter

23 - Well water sample filtered through a 0.45-micron membrane filter

24 - Natural pond water sample filtered through a 0.45 -micron membrane filter

25 - Artificial pond water sample filtered through a 0.45 -micron membrane filter

26 - Spring water sample acidified to a $\mathrm{pH}$ of $\leq 1$ with reagent-grade nitric acid $\left(\mathrm{HNO}_{3}\right)$

27 - Stream water sample acidified to a $\mathrm{pH}$ of $\leq 1$ with reagent-grade nitric acid $\left(\mathrm{HNO}_{3}\right)$

28 - Well water sample acidified to a $\mathrm{pH}$ of $\leq 1$ with reagent-grade nitric $\overline{\text { acid }} \overline{\left(\mathrm{HNO}_{3}\right)}$

29 - Natural pond water sample acidified to a $\mathrm{pH}$ of $\leq 1$ with reagent-grade nitric acid $\left(\mathrm{HNO}_{3}\right)$

30 - Artificial pond water sample acidified to a $\mathrm{pH}$ of $\leq 1$ with reagentgrade nitric acid $\left(\mathrm{HNO}_{3}\right)$ 
SAMPLE

KEY NO. SOURCE / MEDIUM / TREATMENT

31 - Wet spring sediment sample dried at $\leq 100^{\circ} \mathrm{C}$ and sieved to +40 mesh through stainless steel sieves

32 - Wet stream sedilient sample dried at $\leq 100^{\circ} \mathrm{C}$ and sieved to +40 mesh through stainless stael sieves

33 - Wet natural pond sediment sample dried at $\leq 100^{\circ} \mathrm{C}$ and sieved to +40 mesh through stidinless steel sleves

34 - Wet artificial pond sediment sample dried at $\leq 100^{\circ} \mathrm{C}$ and sleved to +40 mesh through stainless steel sieves

35 - Dry stream sediment sample dried at $\leq 100^{\circ} \mathrm{C}$ (if necessary) and sieved to +40 mesh through stainless steel sieves

36 - Wet spring sediment sample dried at $\leq 100^{\circ} \mathrm{C}$ and sieved to -80 mesh through stainless steel sieves

37 - Wet stream sediment sample dried at $\leq 100^{\circ} \mathrm{C}$ and sieved to -80 mesh through stainless steel sieves

38 - Wet natural pond sediment sample dried at $\leq 100^{\circ} \mathrm{C}$ and sieved to -80 mesh through stainless steel sieves

39 - Wet artificial pond sediment sample dried at $\leq 100^{\circ} \mathrm{C}$ and sieved to -30 mesh through stainless steel sieves

40 - Dry stream sediment sample dried at $\leq 100^{\circ} \mathrm{C}$ (if necessary) and sieved to -80 mesh through stainless steel sieves

96 - Dry. natural pond sediment sample dried at $\leq 100^{\circ} \mathrm{C}$ (if necessary) and sieved to $=100$ mesh through stainless steel sieves

97 - Dry artificial pond sediment sample dried at $\leq 100^{\circ} \mathrm{C}$ (if necessary) and sieved to -100 mesh through stainless steel sleves

98 - Other water These key numbers are to be used only for water (98)

99 - other sediment $\left\{\begin{array}{l}\text { or sediment (99) samples coming from a special source } \\ \text { and/or given a special treatment not described for }\end{array}\right.$ any of the types of samples above. When used in a published listing, the source and treatment given the samples so designated must be described in the text of the publication. 


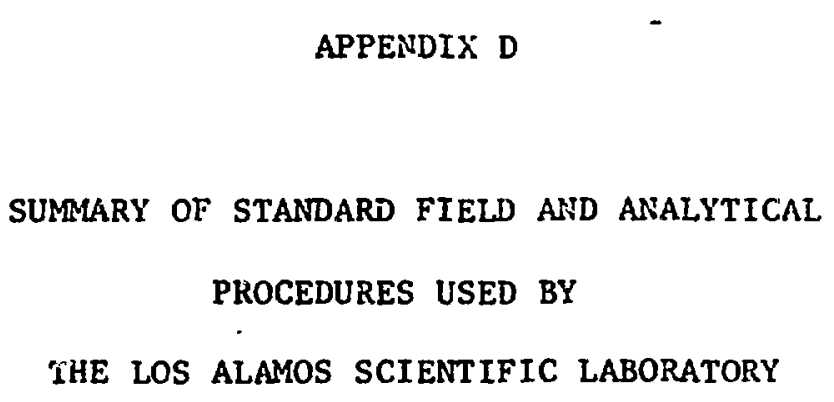

IN THE

NURE HYDROGEOCHEMICAL AND STREAII SEDIMENT RECONNAISSANCE 
APFENDIX ITEM D-I

\author{
SUMMARY OF STANDARD PROCEDURES \\ USED BY \\ THE LOS ALARIOS SCIENTIFIC LABORATORY (LASL) \\ IN THE \\ US ENERGY RESEARCH AND DEVELOPAENT ADMINISTRATION (ERDA) \\ NATIONAL URANIUM RESOURCE EVALUATION (NURE) \\ HYDROGEOCHEMICAL AND STREAM SEDIMENT RECONNAISSANCE (HSSR)
}

\title{
I. FIELD PROCEDURES
}

Water Sampling

Water samples are taken directly from the source wherever possible and placed into pre-washed and staled $25-\mathrm{ml}$ polyethylene vials. These are then acidified to a $\mathrm{pH}$ of $\leq 1$ with $8 \mathrm{~N}$, reagent-grade HNO3. All sample containers are doubly labeled with preprinted, adhesive labels carrying the same sample location number preprinted on the field data form. Springs are sampled as near to their point of emergence as possible; stream waters are taken from fast-flowing current away from the bank; ponds (including small lakes and reservoirs) are sampled from just below the surface, away from the bank; and well waters are taken near the wellhead if the well is pumping or from a holding tank if not.

Sediment Sampling (Wet or Dry)

Enough fine-grained, organic-rich, water-transported sediment to yield a composite sample of $\sim 25 \mathrm{~g}$ after processing (as indicated below) is taken from beneath the water level (where water exists) at three closely adjacent spots at each location. This is done with a polyethylene scoop, after the water sample (if any) is taken. The sediment is put into a new, clean, and originally sealed rip-top, polyethylene bag and properly double-labeled for delivery (with the field data form) to the drying facility. After drying at $\leq 100^{\circ} \mathrm{C}$, each sample is sieved through stainless steel sieves to -100 mesh. The -100 mesh fraction is put into a pre-washed, 25-ml polyethylene vial, appropriately double-labeled (using labels Erom the data form), and sealed for storage at the LASL.

Field Measurements

The air temperature, taken in the shade at the time of sampling, is recorded to the nearest whole degree centigrade. The water temperature is measured in the source water and recorded to the nearest one-half degree centigrade. All temperature measurements are made with quality, precalibrated thermometers. The $\mathrm{pH}$ of the source water is measured with a calibrated, portable $\mathrm{pH}$ meter or multi-range $\mathrm{pH}$ paper, and recorded to the nearest one-tenth of a $\mathrm{pH}$ unit. The specific conductance ( $\mu \mathrm{mho} / \mathrm{cm}$ ) of the source water is measured with a calibrated, temperature compensated $\left(25^{\circ} \mathrm{C}\right.$ ) portable meter after the attached sample cup has first been rinsed three times in the source water. The scintillometer readings, taken on a flat, dry spot within i few meters of the sample location, are measured with a portable scintillometer. Two readings are recorded, the first with a radiation shield in place (blocking out ground radiation), and the second with the shield removed. The readings (in counts/s) are converted by computer to give the equivalent uranium (eU) value set forth in the data listing.

\section{Field Observations}

These represent the best subjective judgment of the field sampler on location, and include very general descriptions of the local bedrock, sediment, water. vegetation, terrain, weather, possible contaminants, and water well configuration, if applicable.

D-2 
Sample Location Verification

Each contractor is supplied field maps with the desired sample types and locations symbolically premarked at the LASL. The maps are normally USGS Quadrangles (either $\mathbf{7 . 5 ^ { \prime }}$ or $15^{\prime}$ ) but, where not available, Forest Service, State Highway, or other reasonably detailed maps are provided. As each location is sampled, a unique sample location number, preprinted on transparent adhesive labels provided with the identically numbered field data forms, is pasted over the precisely marked site on the field map. The latitude and longitude of each location is computed by the sampling contractor. Every location is later checked (and corrected if necessary) at the LASL by overlaying computer produced location plots on the field maps used. The latitudes and/or lnngitudes are corrected if the overlay locations are displaced by more than $300 \mathrm{~m}$ from the locations marked on the field maps. When a desired location cannot be sampled as specified, an alternate sample type or location as near as possible to the original one is picked, and the new sample type and/or location is/are marked on the field map and properly labeled as above. In the case at hand, all sample locations were chosen by the GIUA.

\section{ANALYTICAL PROCEDURES}

Water Samples Amalyzed for Uranium by Fluorometry

In a controlled laboratory environment, a NaF (98\%)-LiF (2\%) flux pellet is prepared and placed on a platinum dish. The $25-\mathrm{ml}$ water vial is vigorously shaken and a $0.25-\mathrm{ml}$ aliequot of water is withdriwn and dropped onto a flux pellet, then evaporated under a heat lamp. The sample flux is then heaced until fused. After it cools, it is excited with ultra-violet radiation in the fluorometer, and the measured fluorescence is read, recorded, and put through a computer routine using standards and blamks run at the same time to obtain the uranium concentration. Water samples which have uranium concentrations in excess of $10 \mathrm{ppb}$ (the upper limit of cetectiom of the fluorometry system without recalibration) are reanalyzed using the delayed meutron counting technique described below.

Water Samples Analyzed for Uranium by Delayed Neutron Counting (DNC)

Only waters with $>10 \mathrm{ppb}$ uranium are assayed using DNC. Samples taken in the 41-ml rabbits are thoroughly cleaned (exterior) before analysis. Samples received in 25-ml ials (used exclusively in some of the early work) are transferred to clean, labeled, 4l-ml rabbits before being analyzed. Each water sample is weighed, and its weight (less that of the rabbit) and location number are recorded. The rabbits are tinen loaded into a 25-sample transfer clip. The reactor pneumatic transfer system amd background radiation levels are checked, and the system is calibrated using four standards. The transfer clip is installed on the pneumatic feed line, and the count control is set (typically, a 60-s irradiation, a 30-s delay, and a 60-s count is used, but this can be changed to accommodate abnormally high or low uranim concentrations). The samples are automatically cycled through the system and the uranium concentration is automatically computed in ppb and entered into the data base. None of the water samples reported were > $10 \mathrm{ppb}$.

Uranium Analysis of Sediment Samples

All sediment samples are analyzed for total uranium by DNC. A split of each sample (dried and sieved as described) is transferred to a clean 4-ml rabbit, weighed (less the tare), and recorded along with the appropriate location number. The readied rabbilts are loaded into a 50 sample transfer c1ip. The reactor pneumatic transfer system and background radiation levels are checked, and the system is calibrated as mbove. The transfer clip is installed and the count control is set (typically, 20-s irradiation, a 10-s delay, and a 20-s count is used). The samples are cycled through the system and the uranium concentration is automatically measured, computed in ppm, and entered into the data base. 


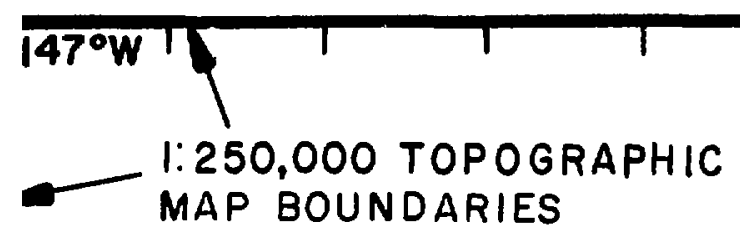

I:250,000 TOPOGRAPHIC

MAP BOUNDARIES

\section{GULKANA}

52

$\mathcal{R}_{-1769}^{1770}$

$1779-0 \cdot 1767$
0
4766

89

$-1788$

$\sim^{1785}$

1783 


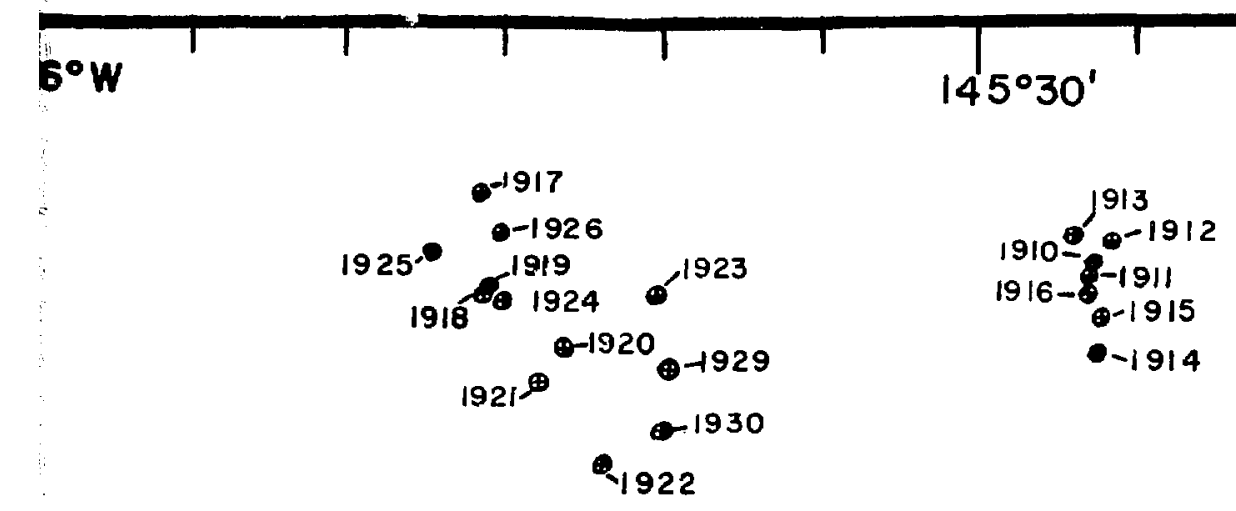




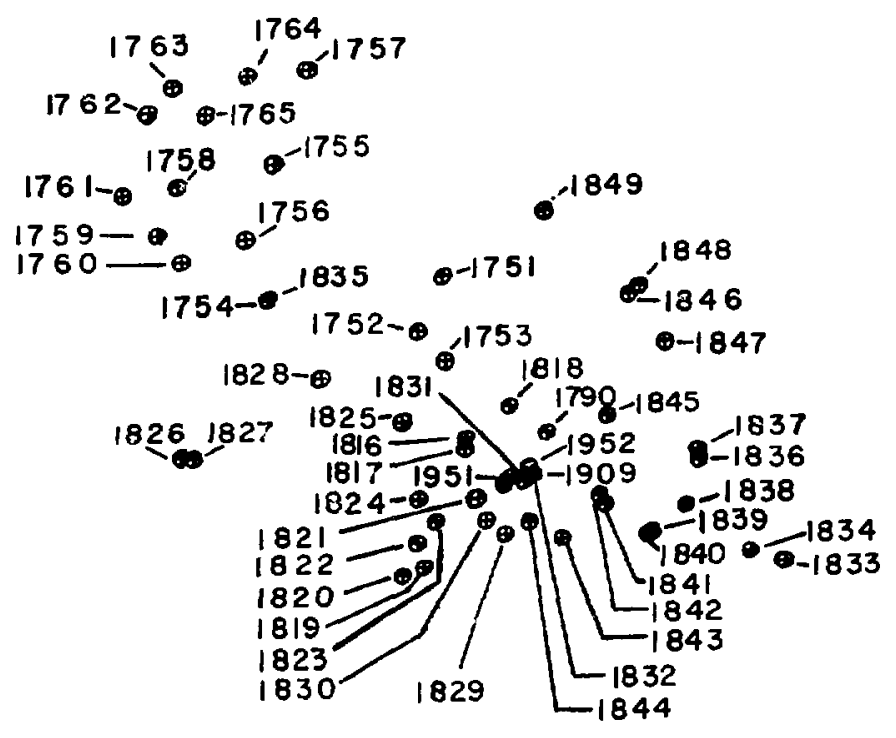

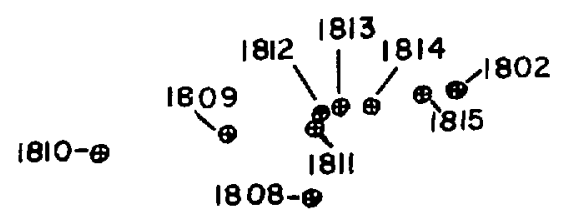

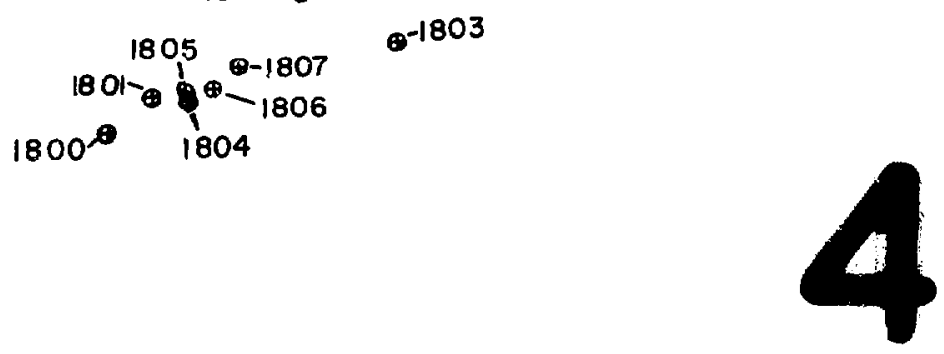



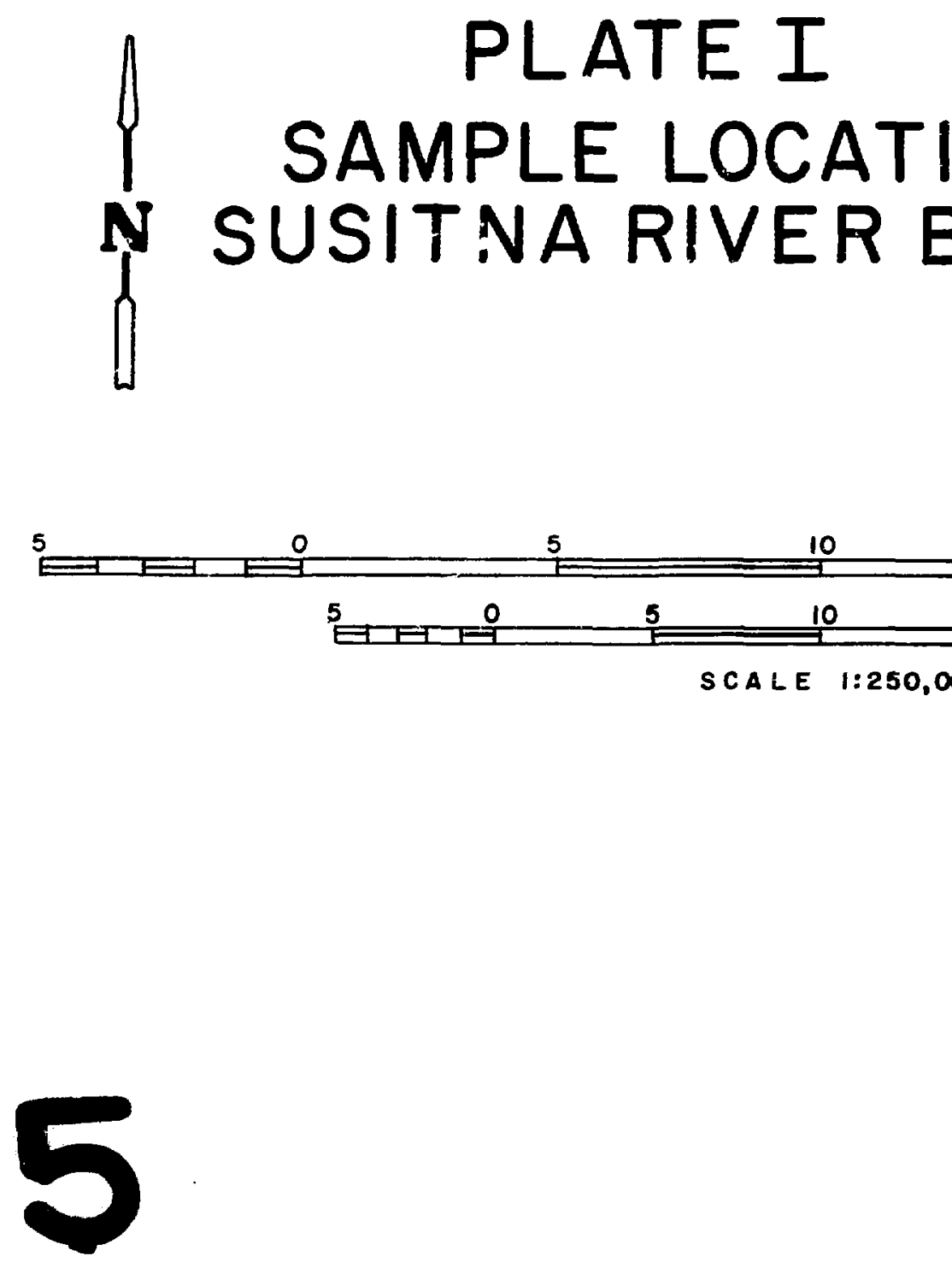

$146^{\circ} 30^{\prime}$

$146^{\circ}$ 


\section{ATION OVERLAY \\ R BASIN, ALASKA}

\section{o}

15

20

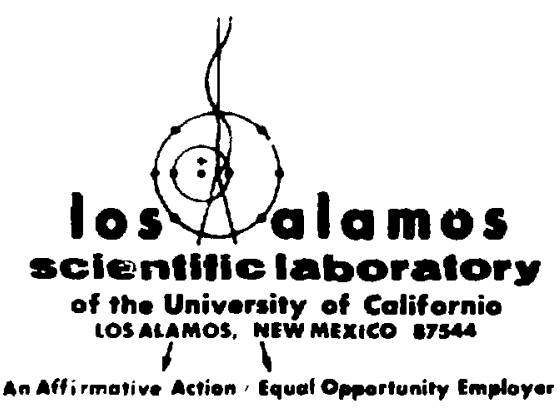
25 Miles

$2 \quad 15 \quad 20 \quad 25$ Kilometers

$1: 250,000$

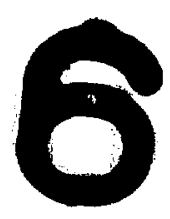




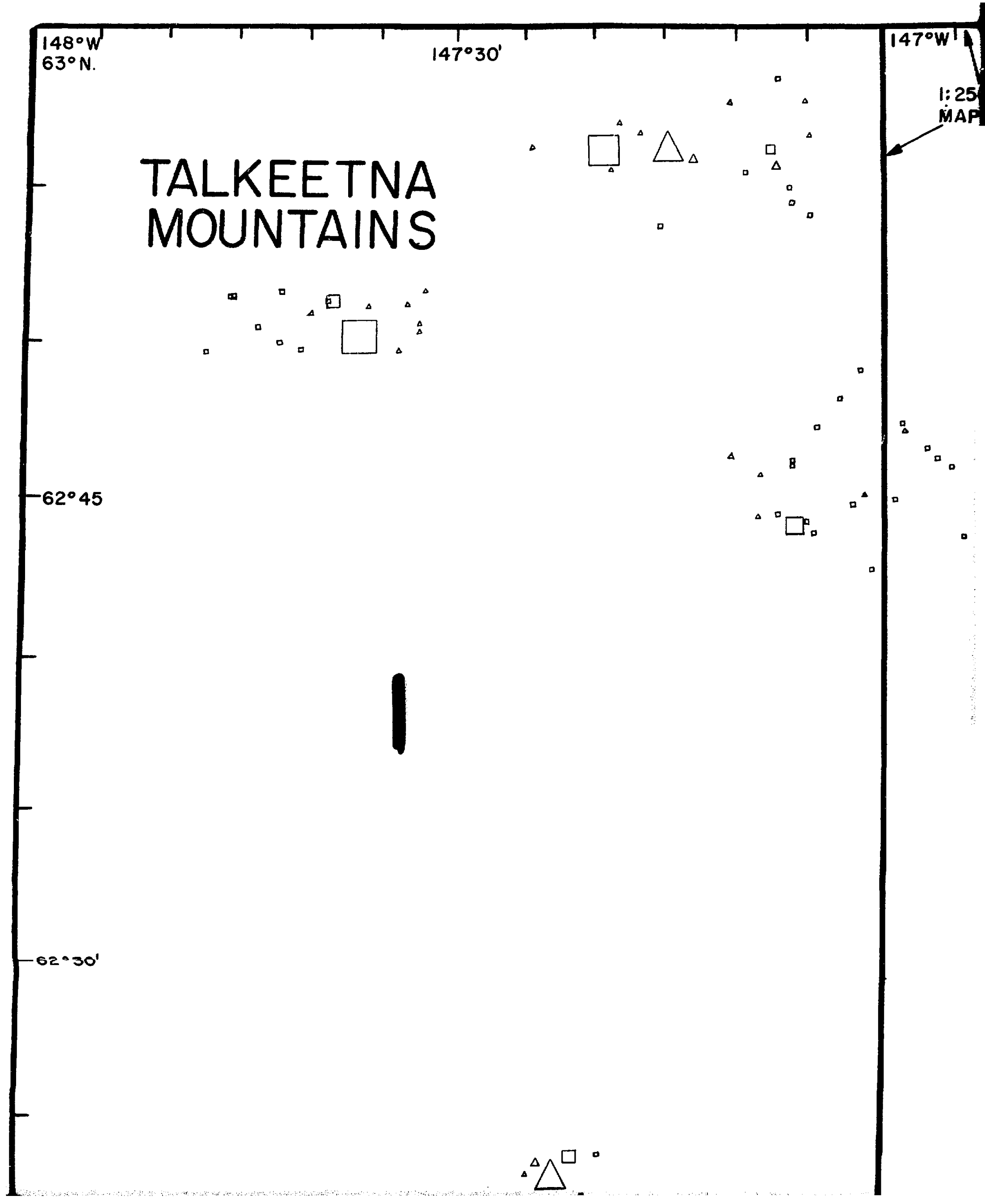


I: 250,000 TOPGRAPHIC

MAAP BOUNDARIES

\section{GULKANA}




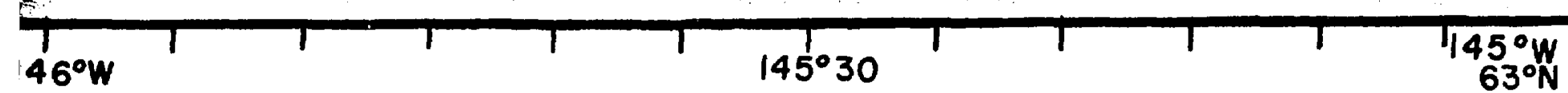

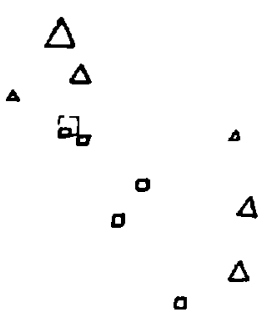

$62^{\circ} 45^{\prime}$

$62^{\circ} 30^{\prime}$ 

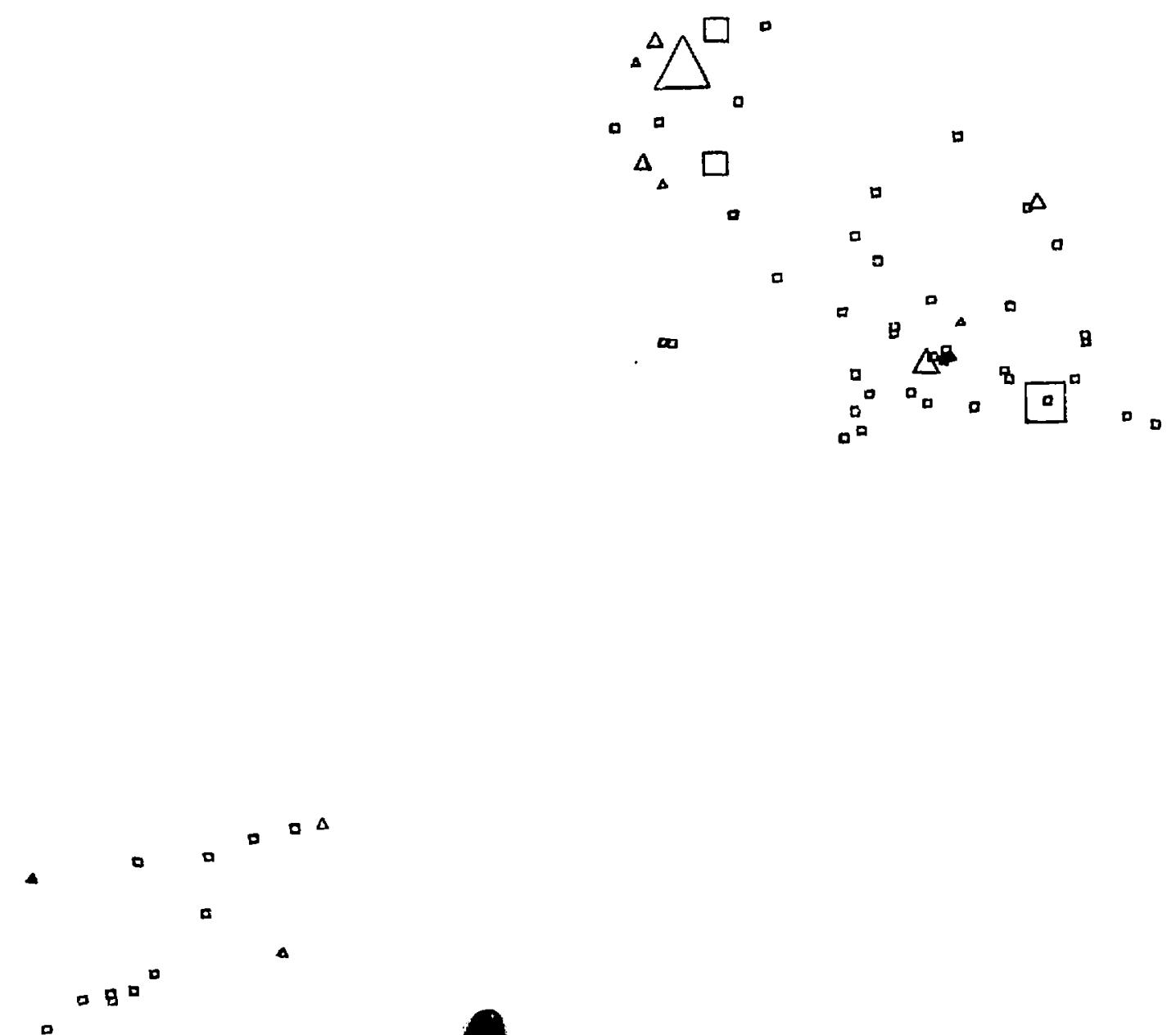


\section{PLATE II \\ URANIUM CONCENTRATION OVER SUSITNA RIVER BASIN, A}

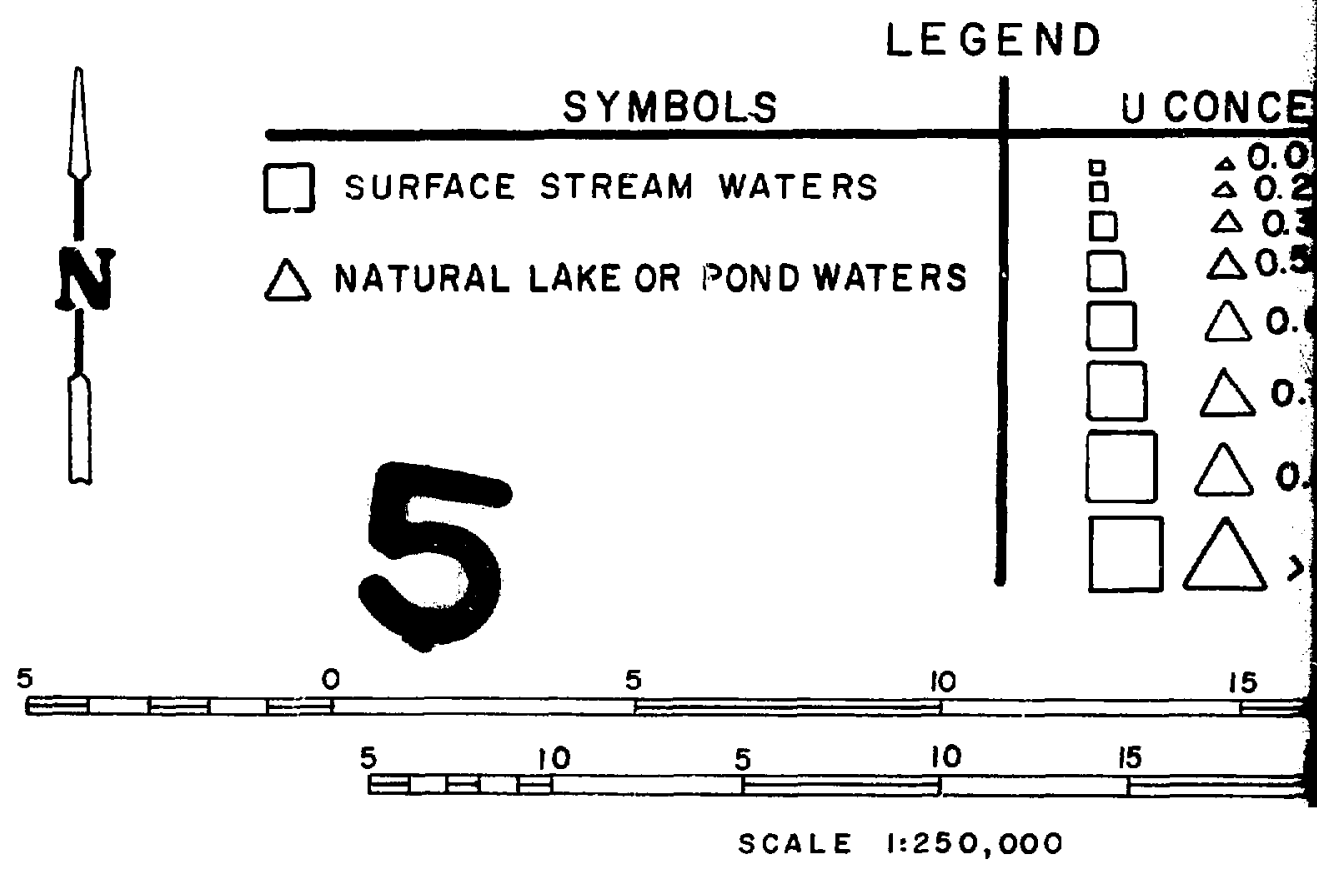




\section{OVERLAY (WATER, pp b ) SIN, ALASKA}

D

U CONCENTRATION (ppb)

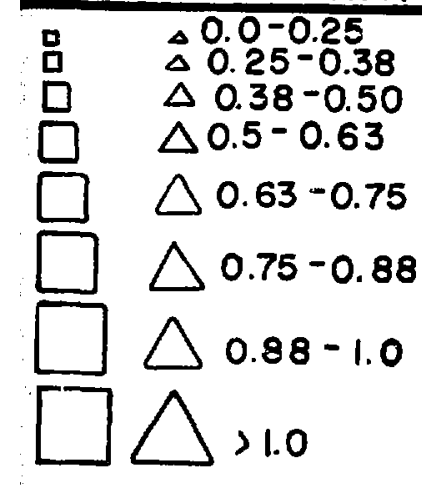

15

20

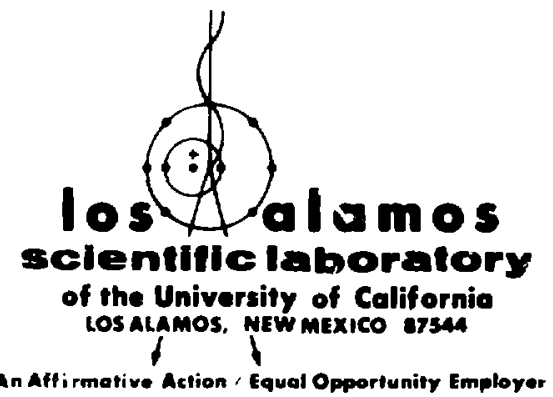

25 Miles

15

20

25 Kilometer

' 


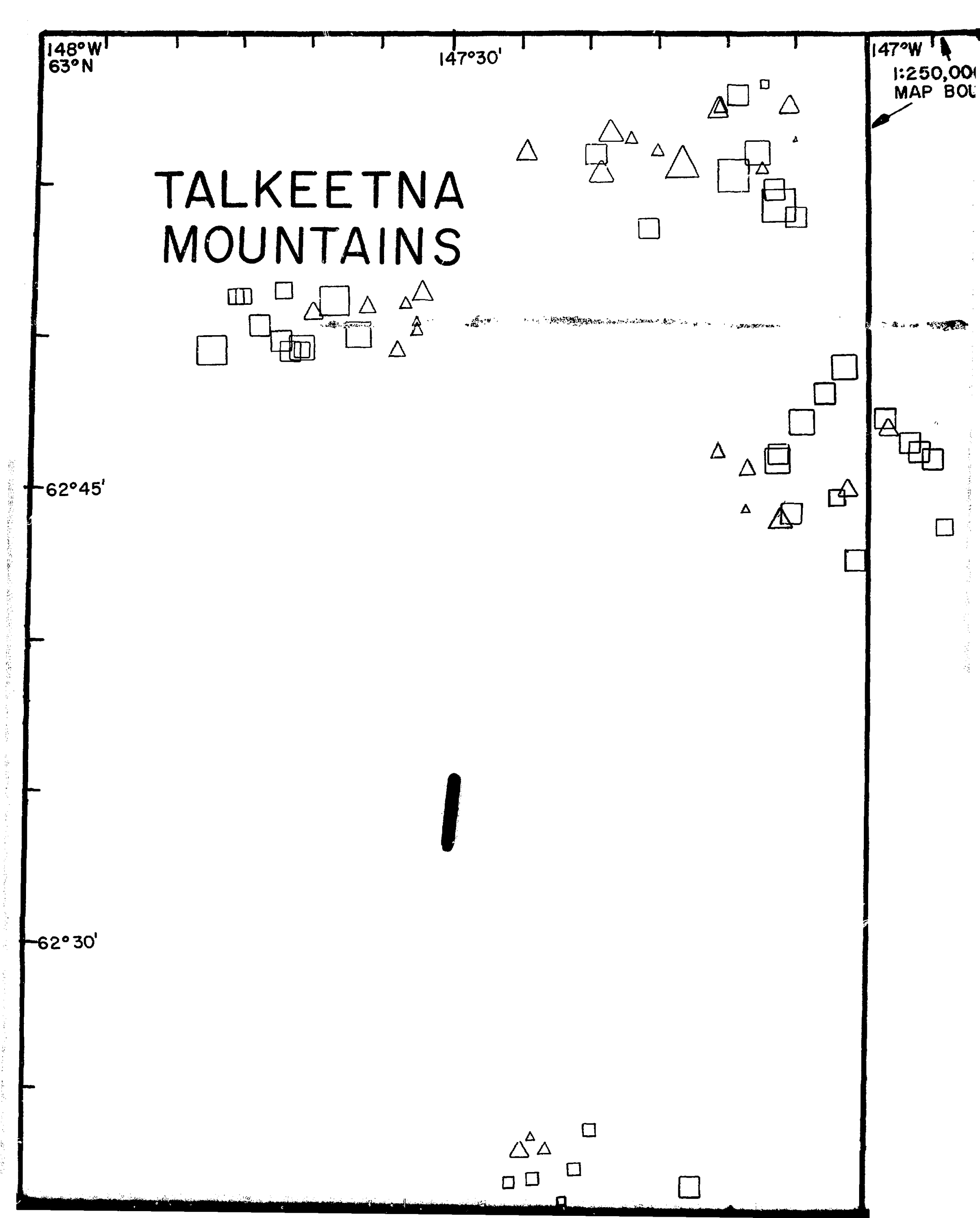


AP BOUNDARIES

\section{GULKANA}




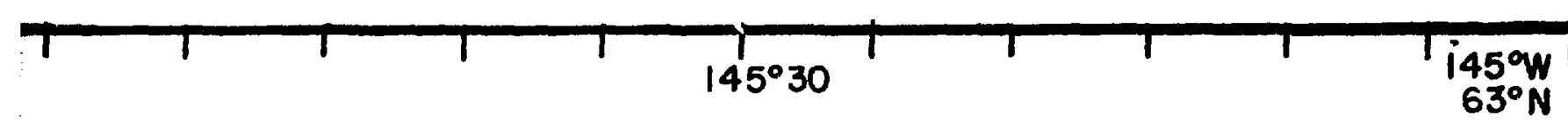
$\triangle \stackrel{\Delta}{\triangle}$
望
$\square \triangle$

$62^{\circ} 45^{\prime}$

$62^{\circ} 30^{\prime}$ 


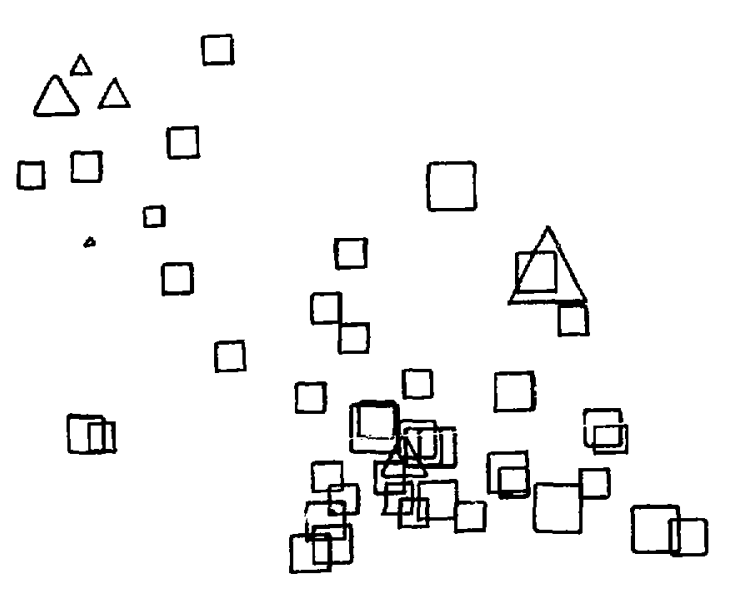

$-62^{\circ} 15^{\prime}$

$$
\begin{aligned}
& \Delta \quad \square \quad \square \\
& \Delta
\end{aligned}
$$




\section{PLATE III \\ URANIUM CONCENTRATION OV SUSITNA RIVER BAS}

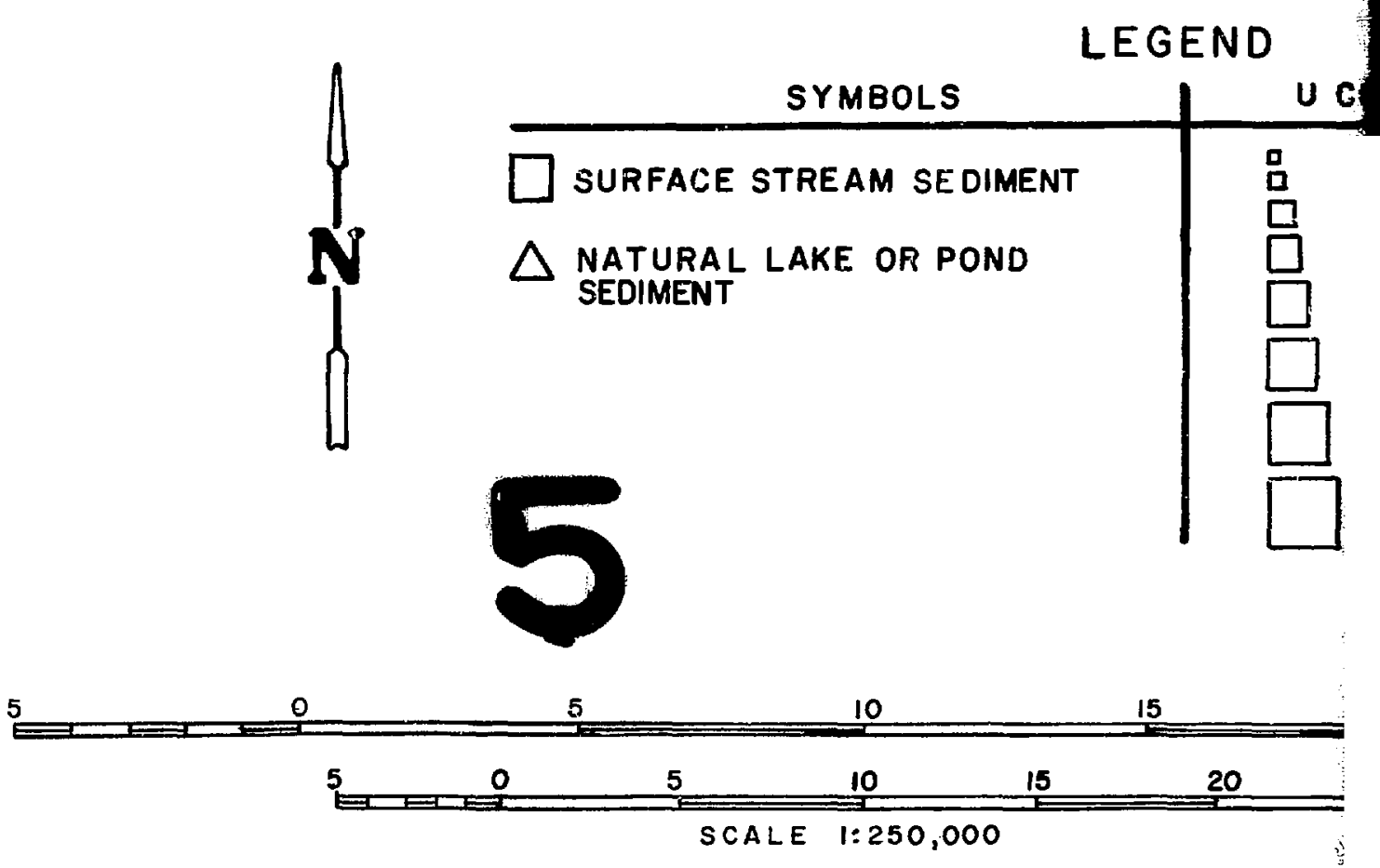




\section{PN OVERLAY (SEDIMENTS,ppm) BASIN, ALASKA}

EGEND

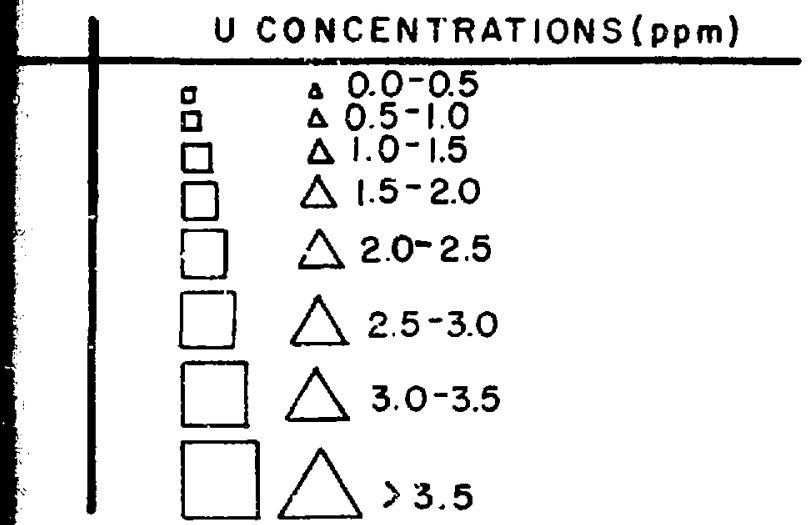

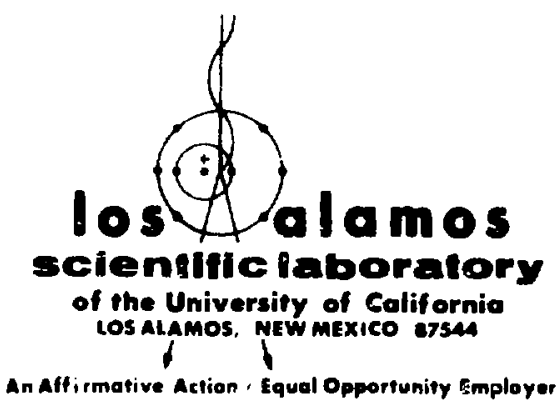

